\title{
Konserwacja i badania technologiczne obrazu Św. Katarzyna Aleksandryjska Hansa Süssa von Kulmbach z Muzeum Narodowego w Krakowie - Muzeum Książąt Czartoryskich
}

\author{
MAtGORZATA CHMIELEWSKA \\ Muzeum Narodowe w Krakowie \\ e-mail: mchmielewska@mnk.pl \\ ORCID: 0000-0002-3220-4935
}

Keywords: Kraków, Hans Süss von Kulmbach, religious painting, Princes Czartoryski Collection, restoration, panel painting, painting techniques, technology, history of art restoration and conservation, Alois Hauser

Słowa kluczowe: Kraków, Hans Süss von Kulmbach, malarstwo sakralne, Kolekcja Książąt Czartoryskich, konserwacja, malarstwo sztalugowe, technologia, historia konserwacji, Alois Hauser

\section{Abstract}

The Restoration and Investigation of the Technology of Kulmbach's Saint Catherine of Alexandria from the National Museum - the Princes Czartoryski Museum in Krakow

Between 1999-2001 the author carried out an extensive restoration of a painting Saint Catherine of Alexandria from the Princes Czartoryski Collection, identified to be part of the Marian triptych created by Hans Kulmbach for the monastery of the Order of Saint Paul the First Hermit in Kraków. The original part of the painting has the shape of an oval, which was presumably cut out of a full-figure representation on the reverse of the triptych wing. At the early $20^{\text {th }}$ century the painting underwent extensive restoration, in the process of which it was enlarged and reshaped into a rectangle. Missing details were also painted on the added area. These additions have now been 
discarded with the exception of the changes introduced to the panel support. Only the original painting in a new fitted frame has been exhibited. Physicochemical analysis has been conducted, shedding light on many details of the structural composition of the artwork as well as on the master's technique.

\section{Abstrakt}

W latach 1999-2001 autorka przeprowadziła kompleksową konserwację obrazu Św. Katarzyna Aleksandryjska z Kolekcji Książąt Czartoryskich, który identyfikowany jest z tryptykiem maryjnym namalowanym przez Hansa Kulmbacha dla klasztoru oo. Paulinów na Skałce. Oryginalna część obrazu ma kształt owalu, który prawdopodobnie został wycięty z całopostaciowego przedstawienia umieszczonego niegdyś na rewersie skrzydła tryptyku. Obraz na początku XX wieku poddano gruntownej konserwacji, w trakcie której powiększono go, zmieniając kształt na prostokątny, a na dodanej partii wykonano malarskie uzupełnienia. Obecnie zrezygnowano z wykonanych wówczas rekonstrukcji zachowując zmiany wprowadzone w obrębie podobrazia. Wyeksponowano wyłącznie oryginalne malowidło w odpowiednio zaprojektowanej nowej oprawie. Integralną częścią konserwacji było wykonanie badań fizykochemicznych, dzięki którym możliwe było określenie wielu szczegółów budowy technologicznej obrazu oraz techniki warsztatowej mistrza.

Na zorganizowanej na przełomie 2018 i 2019 roku przez Muzeum Narodowe w Krakowie wystawie „Mistrz i Katarzyna. Hans von Kulmbach i jego dzieła dla Krakowa" zaprezentowano kilkanaście dzieł tego wybitnego malarza niemieckiego renesansu. Hans Süss, który w swoim monogramie $H K$ umieścił pierwszą literę nazwy rodzinnego miasta Kulmbach, uczył się w warsztacie Albrechta Dürera. Będąc pod wpływem swojego mistrza, a także przybyłego z Włoch Jacopa de Barbari, wypracował jednak własny, rozpoznawalny styl. Uzyskanie obywatelstwa Norymbergi w 1511 roku, a także znajomość z Dürerem pozwoliły mu na założenie w tym mieście znakomicie prosperującego warsztatu malarskiego, który realizował wiele prestiżowych zamówień1. Na wystawie pokazane zostały przede wszystkim obrazy pierwotnie stanowiące części kilku ołtarzy wykonanych przez Kulmbacha dla krakowskich kościołów² ${ }^{2}$ pochodzący z bazyliki mariackiej cykl sześciu obrazów z życia

1 Masza Sitek, „Uczeń Dürera w Polsce’ - między źródłem a interpretacją,” w Mistrz i Katarzyna. Hans von Kulmbach i jego dzieła dla Krakowa, red. Mirosław P. Kruk, Aleksandra Hola, i Marek Walczak (Kraków: Muzeum Narodowe, 2019), 39-81.

2 Zdjęcia z wystawy „Mistrz i Katarzyna. Hans von Kulmbach i jego dzieła dla Krakowa,” Muzeum Narodowe w Krakowie (dalej: MNK), Pałac Biskupa Ciołka, Kraków, fot. Artdone, https://artdone.wordpress.com/2019/01/19/hans-suess-von-kulmbach-w-krakowie/\#jp-carousel-60529, dostęp 30 kwietnia 2021. 
św. Katarzyny Aleksandryjskiej, który zaprezentowano po raz pierwszy po kompleksowej konserwacji, oraz predella z retabulum św. Janów z kaplicy Bonerowskiej; ponadto dwa obrazy, które według przeważającej opinii ekspertów pochodzą ze skrzydeł tzw. tryptyku maryjnego z kościoła oo. Paulinów Na Skałce ${ }^{3}$ : Ucieczka do Egiptu oraz Św. Katarzyna Aleksandryjska, należąca do Kolekcji Książąt Czartoryskich. Ołtarz maryjny w nieokreślonym czasie został prawdopodobnie usunięty z wnętrza kościoła i pofragmentowany na oddzielne obrazy ${ }^{4}$. Jego część środkowa, przedstawiająca Pokłon Trzech Króli, z widoczną sygnaturą Kulmbacha i datą 1511, eksponowana jest w Staatliche Museen Preußischer Kulturbesitz - Gemäldegalerie w Berlinie. W klasztorze Paulinów z zamówionego u Kulmbacha dzieła pozostała obecnie jedynie kwatera awersu prawego skrzydła, przedstawiająca Ucieczkę do Egiptu, z zachowanym na jej odwrociu fragmentem dolnej części kobiecej postaci - św. Barbary, która widniała na rewersie. Historia zaginionej drugiej części tego skrzydła, a także lewego skrzydła tryptyku z przedstawieniem św. Katarzyny nie jest do końca wyjaśniona. Zainspirowana przywołaną na wstępie wystawą chciałam powrócić do tego niezwykle ciekawego tematu, omawiając efekty przeprowadzonej przeze mnie przed dwudziestu laty gruntownej konserwacji obrazu Św. Katarzyna Aleksandryjska z Kolekcji Książąt Czartoryskich, który identyfikowany jest z podzielonym niegdyś ołtarzem (il. 1).

Owalny obraz przedstawiający św. Katarzynę Aleksandryjską w ujęciu półpostaciowym ${ }^{5}$ został zakupiony do Muzeum Książąt Czartoryskich w 1895 roku od pełniącego funkcję przedprzeora zakonu oo. paulinów księdza Ambrożego Federowicza ${ }^{6}$. Nie wiadomo niestety, dokąd trafiły i czy nadal istnieją pozostałe fragmenty lewego skrzydła tryptyku. W kilka lat po zakupie obrazu przez Czartoryskich, w „Sprawozdaniach Komisji do Badań Historii Sztuki”

3 Obecnie badacze bardzo ostrożnie wypowiadają się o proweniencji tego ołtarza. Obraz Ucieczka do Egiptu oraz przycięty do formy owalu fragment wyobrażenia św. Katarzyny pojawił się w inwentarzu klasztoru oo. Paulinów Na Skałce dopiero w 1875 r., por. Aleksandra Hola i Masza Sitek, „Hans von Kulmbach (†1522), 'Św. Barbara’ (rewers, dolna część), 1511(?)," w Mistrz i Katarzyna, 310.

4 Podobny los spotkał również inne retabula autorstwa Kulmbacha, zarówno ze scenami z życia św. Katarzyny Aleksandryjskiej z kościoła Mariackiego, jak i św. Jana Ewangelisty z bazyliki św. Floriana (pierwotnie przeznaczonego dla kaplicy Bonerowskiej).

5 Tempera na desce lipowej, 56,0 × 38,2 cm, ok. 1511 r., nr inw. MNK XII-328, zob. m.in. notę katalogową Dorota Dec, „Hans Süss von Kulmbach (†1522), 'Św. Katarzyna Aleksandryjska,' ok. 1511,” w Mistrz i Katarzyna, 312 (tu zestawiona bibliografia).

6 Zob. Biblioteka Książąt Czartoryskich w Krakowie, rkps 12409 [Muzeum i Biblioteka w Krakowie, Kwity i dowody wydatków muzealnych i bibliotecznych. 1895], kwit nr 10593. 
z 1902 roku znana historyk sztuki Konstancja Stępowska opisała stan zachowania wizerunku św. Katarzyny tymi słowami: „obraz ten [...] w chwili, gdy się dostał do Muzeum Czartoryskich był bardzo zabrudzony i zniszczony, - przytem ci, którzy wycinali postać świętej z większej całości, nadali wycinkowi kształt owalny, tak sprzeczny z całym jego charakterem" 7 . Z przytoczonego opisu wynika, że obraz Kulmbacha po zakupieniu wymagał gruntownej konserwacji. Podłoże, oprócz zmiany kształtu, zostało znacznie ścienione, zapewne w wyniku przecięcia dwustronnie malowanego fragmentu ołtarza na dwa oddzielne obrazy, podobnie jak górna część prawego skrzydła tryptyku Niewielkiej grubości podobrazie osłabiały dodatkowo uszkodzenia spowodowane przez owady, a być może również pęknięcia powstające na łączeniu desek. Konserwację wizerunku św. Katarzyny ${ }^{9}$ zlecono wybitnemu specjaliście, głównemu konserwatorowi galerii malarstwa w Kaiser-Friedrich-Museum w Berlinie, prof. Aloisowi Hauserowi zwanemu Młodszym ${ }^{10}$, synowi i współpracownikowi równie renomowanego konserwatora malarstwa w Starej Pinakotece w Monachium ${ }^{11}$. Kolekcjonerzy doceniali jego doświadczenie ${ }^{12}$, powierzając mu renowację najcenniejszych dzieł malarstwa europejskiego z polskich zbiorów, wśród nich również obiekty z Muzeum Książąt Czartoryskich ${ }^{13}$.

7 Konstancja Stępowska, „Przyczynki do stosunków Kulmbacha z Polską i do jego działalności w Krakowie," Sprawozdania Komisji do Badań Historii Sztuki 8, z. 1-2 (1907): szp. XX, przyp. 1.

8 Górna część skrzydła została podzielona w swej grubości na dwie sceny: Ofiarowanie i $S$ w. Barbarę, Stępowska, „Przyczynki,” szp. XXII, przyp. 3.

9 Jej zakres został określony podczas badań towarzyszących wykonanej blisko sto lat później konserwacji. Poczynione wówczas spostrzeżenia zostały krótko opisane przez Jerzego Żmudzińskiego, „Restauracja zabytków malarstwa ze zbiorów polskich w pracowni berlińskiego konserwatora Aloisa Hausera Mł. (1857-1919)," w Wobec zabytku... Tradycje i perspektywy postaw. Studia dedykowane pamięci prof. Jerzego Remera, red. Elżbieta Pilecka i Juliusz Raczkowski (Toruń: Wydawnictwo Naukowe UMK, 2010), 155-156.

10 Jerzy Żmudziński, „Restauracja zabytków malarstwa sztalugowego w działalności Krakowskiego Towarzystwa Opieki nad Polskimi Zabytkami Sztuki i Kultury (1902-1926),” Rocznik Biblioteki PAN w Krakowie 42 (1997): 189.

11 „Dokumentacja prac konserwatorskich i restauratorskich. Sześć obrazów na drewnie autorstwa Hansa Süssa z Kulmbachu ( 1480-1522) ze zbiorów Bazyliki Mariackiej w Krakowie,” praca zbiorowa, oprac. dokumentacji pisemnej Aleksandra Hola (dokumentacja konserwatorska, Kraków 2015, wersja elektroniczna: Archiwum Bazyliki Mariackiej w Krakowie, sygn. ABMar, R323), 23.

12 Żmudziński, „Restauracja zabytków malarstwa ze zbiorów,” 146.

13 W 1898 r. trafił do niego m.in. obraz Rembrandta Pejzaż z miłosiernym Samarytaninem, zob. Anna Grochowska-Angelus i Katarzyna Novljaković, „Podpatrywanie mistrza - o Rembrandta ‘Krajobrazie z miłosiernym Samarytaninem’ raz jeszcze,” w Wobec zabytku, 230. 
Obraz wrócił do Krakowa przed 1902 rokiem $^{14}$. Konstancja Stępowska w dalszej części cytowanego tekstu tak opisała efekty tej konserwacji: „Prof. Hauser z Berlina, któremu obraz ten posłano do restauracyi, uważał za stosowne dopełnić kształt wycinka do prostokątnej formy. Zrobił to wprawdzie po mistrzowsku tak, że tylko oko wytrawnego znawcy dostrzeże domalowanie, ale obraz na tem stracił, gdyż nie jest cały ręki Kulmbacha. Restauracya trochę za silnie uwydatniła białe światło na okół warg i oczu, czego pierwotnie nie było i odebrała słodycz wyrazowi twarzy, nadając jej nieprzyjemny grymas”. Po wielu latach nawet tak mistrzowsko wykonane „domalowanie” uwydatniło się w wyniku pociemnienia spoiwa, co obok pojawiających się niewielkich złuszczeń warstwy malarskiej było głównym powodem podjęcia w 1999 roku decyzji o ponownej konserwacji-restauracji. Konsekwencją nieodwracalnych zmian kolorystycznych dodanych przez Hausera fragmentów była konieczność ich usunięcia i zaaranżowania tych partii na nowo. Tym razem przyjęto jednak inną niż poprzednio koncepcję konserwacji, decydując się na wyeksponowanie zachowanych fragmentów oryginalnej kompozycji bez uzupełniania brakujących elementów.

Integralną częścią prac konserwatorskich było wykonanie szczegółowych badań technologicznych obiektu. Oprócz wnikliwej obserwacji obrazu w świetle bocznym i w powiększeniu, wykonano fotografie w światłach analitycznych (UV, IR, RTG). Badania laboratoryjne obejmowały rozpoznanie dendrologiczne oraz analizę mikroskopową i mikrochemiczną spoiw i pigmentów ${ }^{15}$. Dostarczyły one wielu informacji na temat stanu zachowania obrazu, zmian, jakim ulegał on na przestrzeni swojej historii oraz techniki warsztatowej.

Kompleksowa konserwacja tak wybitnego dzieła, poparta badaniami, umożliwia dostrzeżenie często niewidocznych wcześniej szczegółów techniki

14 Stępowska, „Przyczynki,” szp. VI-VII.

15 Analiza stratygraficzna oraz identyfikacja pigmentów, spoiw i zapraw z próbek pobranych z obrazu Św. Katarzyna Aleksandryjska została wykonana w 1999 r. przez dr Marię Rogóż oraz dr. Pawła Karaszkiewicza w Zakładzie Chemii Konserwatorskiej; identyfikację dendrologiczną przeprowadził Jan Ptak w Zakładzie Materiałoznawstwa oraz Historii Technik Dzieł Sztuki. Badania w technikach rentgenografii oraz reflektografii w podczerwieni wykonał dr Jan Rutkowski w Zakładzie Fizyki Stosowanej Wydziału Konserwacji i Restauracji Dzieł Sztuki Akademii Sztuk Pięknych (dalej: WKiRDS ASP) w Krakowie; zob. Małgorzata Chmielewska, „Dokumentacja konserwatorska Hans Süss von Kulmbach nr inw. MNK XII-328” (dokumentacja konserwatorska, Kraków 2000, Pracownia Konserwacji Malarstwa i Rzeźby Polichromowanej w Muzeum Książąt Czartoryskich w Krakowie). Zdjęcie w podczerwieni zostało powtórzone w 2018 r. przez Piotra Frączka i Michała Obarzanowskiego w Laboratorium Analiz i Nieniszczących Badań Obiektów Zabytkowych (dalej: LANBOZ) MNK. 
wykonania, charakterystycznych dla danego twórcy. Powtarzalne prawidłowości budowy technologicznej i użytych materiałów mogą być również pomocne przy wyjaśnieniu wątpliwości dotyczących atrybucji innych dzieł niesygnowanych, których historia nie jest w pełni udokumentowana. W przypadku omawianego obrazu wykonane badania fizykochemiczne umożliwiły zidentyfikowanie większości użytych przez mistrza materiałów, co wraz z poczynionymi w trakcie konserwacji obserwacjami pozwala na dość dokładne opisanie techniki, jaką się posługiwał. Podobrazie, które pierwotnie stanowiło skrzydło ołtarzowe, wykonane zostało z drewna lipowego ${ }^{16}$, prawdopodobnie z trzech desek sklejonych na styk, bez dodatkowych wzmocnień. Drewniana tablica, której wysokość mogła wynosić około $156 \mathrm{~cm}^{17}$, została bardzo starannie wyrównana i oprawiona $\mathrm{w}$ ramy ${ }^{18}$. Bezpośrednio na przygotowane podłoże naniesiono obustronnie niezbyt grubą warstwę białej zaprawy sporządzonej z kleju białkowo-glutynowego i kredy ${ }^{19}$. Na wygładzonej zaprawie artysta swobodnie szkicował postać: na zdjęciach wykonanych w podczerwieni uwidacznia się wstępny rysunek koncepcyjny (il. 2). Poprawki Kulmbacha, tzw. pentimenti, najwyraźniejsze są w partii korony. Jej kształt został zaznaczony szkicową, delikatną linią. Później malarz starannie dopracował rysunek mocniejszą kreską, zarówno piórem, jak i pędzlem. Rysunek kompozycji jest czytelny w miejscach, w których warstwy oryginalnego malowidła z upływem czasu utraciły swoje właściwości kryjące bądź zostały przetarte. Można go zauważyć w partii twarzy lub pojedynczych kosmyków, gdzie jest wykonany cienką kreską, zapewne piórem (il. 3), a także w partii szat, gdzie wyraźnie widoczne są szersze, płynne linie szrafowania modelujące suknię

16 Próbkę do badań pobrano z odsłoniętego w wyniku ubytku warstw malarskich podobrazia. Na podstawie obserwacji obrazu mikroskopowego identyfikację dendrologiczną przeprowadził mgr Jan Ptak w Zakładzie Materiałoznawstwa oraz Historii Technik Dzieł Sztuki WKiRDS ASP w Krakowie.

17 Szerokość podłoża obrazu Ucieczka do Egiptu wynosi $52 \mathrm{~cm}$, wysokość $81 \mathrm{~cm}$, gdy dodamy do niego wysokość zaginionej kwatery z Ofiarowaniem, otrzymamy przypuszczalną wysokość całego skrzydła, która wynosiłaby $156 \mathrm{~cm}$ i byłaby prawie równa wysokości obrazu Pokłon Trzech Króli z Gemäldegalerie w Berlinie.

18 Podłoże osadzano w ramie przed gruntowaniem. Na kwaterze Ucieczka do Egiptu widoczne są lekko zawinięte do góry krawędzie zaprawy, niezakrywającej brzegów podobrazia, pierwotnie wpuszczonych w ramy. Trudno jednoznacznie stwierdzić, czy były to ramy robocze, czy docelowe, zob. Sitek, „'Uczeń Dürera w Polsce’,” 79.

19 W badaniu pobranej z obiektu próbki zaprawy zidentyfikowano węglan wapnia oraz pasma pochodzące od spoiwa białkowego typu klej glutynowy. Analizę spoiwa metodą spektrofotometrii w podczerwieni przeprowadziła dr Maria Rogóż w Zakładzie Chemii Konserwatorskiej WKiRDS ASP w Krakowie. 
świętej, w cieniach pogłębione jeszcze lawowaniem. Jego kolor nadaje chłodniejszy odcień naniesionym w tych partiach barwom. Analiza przekrojów bocznych z wykonanych w trakcie prac konserwatorskich szlifów wskazuje, że pomiędzy zaprawą a malowidłem występuje warstwa kleju o żółtobrązowym odcieniu, która izolowała chłonną zaprawę od położonych na niej warstw malarskich. Warstwa ta utrwaliła rysunek, jednocześnie nadając całemu malowidłu jednolity złotawy ton (il. 4). Autor wykorzystał biały kolor zaprawy, aby osiągnąć wyjątkową świetlistość i czystość barw. Zasadnicze pigmenty palety malarskiej zostały zidentyfikowane w wyniku przeprowadzonych badań chemicznych ${ }^{20}$, były to: biel ołowiowa, żółcień cynowo-ołowiowa, gumiguta, ochra żółta, cynober, kraplak, azuryt, umbra naturalna i palona oraz czerń węglowa. W wyniku badania spoiwa potwierdzono, że obraz wykonano $\mathrm{w}$ technice temperowej ${ }^{21}$.

Malowidło budowane jest stopniowo przez nakładanie rozwodnionych, lekko przejrzystych warstw farby. Twarz, o ugrowoszarej w cieniach i różowej na policzkach karnacji została bardzo delikatnie wymodelowana. Na granicach światła i cienia widzimy, jak przejścia od jednego koloru do drugiego miękko się w siebie wtapiają. Najjaśniejsze miejsca podkreślone zostały gęstą, prawie czystą bielą ołowiową. Refleksy na klejnotach i delikatne linie włosów mają charakterystyczną dla malarstwa temperowego ostrość i precyzję (il. 5). Na obrazie Kulmbacha zostały one namalowane żółcienią cynowo-ołowiową. Szaty świętej: ciemnoróżowa suknia (na jej odcień składa się mieszanina cynobru z dodatkiem kraplaku i czerni węglowej), niebiesko-różowa pelerynka oraz spływający z prawego ramienia jasnozielony płaszcz, malowane są szerszymi pociągnięciami, możemy wyraźnie rozpoznać kierunek i sposób prowadzenia pędzla, zdecydowanie określającego formę anatomicznych szczegółów i draperii. Mieniące się kolory pelerynki i płaszcza przypominają efekt cangiante, stosowanej w malarstwie weneckim metody malowania światłocienia przez dodanie nowego koloru zamiast walorowego przyciemniania (il. 6). Farba w partiach cienia, mimo nakładania kilku kolejnych warstw

20 Materiał uzyskany z obrazu, z partii szat i pejzażu, przeanalizowano stosując metody mikroskopowe i mikrochemiczne. Badania zostały wykonane przez dr Marię Rogóż w Zakładzie Chemii Konserwatorskiej WKiRDS ASP w Krakowie.

${ }^{21}$ Próbka pobrana z partii czerwonej sukni została zbadana metodą spektrofotometrii absorpcyjnej w podczerwieni. Widma IR zarejestrowano na spektrofotometrze AccuLab 6 firmy Beckman w zakresie od 4000 do $250 \mathrm{~cm}^{-1}$. W widmie IR występują pasma przy częstościach 1540, 1640 i $1730 \mathrm{~cm}^{-1}$ pochodzące od spoiwa białkowego oraz przy 720, 975, 1100, 1160, 1415 i $1730 \mathrm{~cm}^{-1}$ pochodzące od oleju schnącego. 
modelunku, zachowała lekkość i przejrzystość, z którą kontrastują znacznie pogrubione partie światła, malowane z użyciem bieli. Płaszcz świętej artysta namalował z rozmachem, kryjącą warstwą gruboziarnistego azurytu zmieszanego z żółcienią cynowo-ołowiową (il. 7).

$\mathrm{Na}$ podstawie zachowanego fragmentu szat św. Barbary na rewersie Ucieczki do Egiptu oraz archiwalnych fotografii możemy sobie wyobrazić, jak mogły wyglądać brakujące części kompozycji (il. 8, 9, 10). Płaszcz św. Katarzyny prawdopodobnie spływał swobodnie w łamiących się fałdach aż do jej stóp ${ }^{22}$, a postać ukazana była w półkoliście zwieńczonym oknie, otwartym na rozległy pejzaż ${ }^{23}$. Krajobraz w tle został opracowany miękko, bez wstępnego rysunku, w charakterystycznym niebieskawym kolorycie. Widoczna na bliższym planie kępa drzew namalowana została azurytem na przeświecającym ugrowym podkładzie, dlatego powstaje wrażenie błękitu o odcieniu wpadającym w zieleń. Obraz był wykończony warstwami olejnych laserunków ${ }^{24}$, które tylko w nielicznych miejscach oparły się mocnym środkom czyszczącym dawnych restauratorów. W przekroju bocznym, wykonanym z próbki pobranej z partii czerwonej sukni, można wyodrębnić cienką warstwę laserunkowej czerwieni - kraplaku (il. 11). Również w miejscu, gdzie artysta namalował wnękę okienną, zidentyfikowano ciekawą mieszaninę pigmentów, wskazującą na laserunkowe wykończenie partii cienia. Jest to mieszanina umbry naturalnej z umbrą paloną oraz wtrąceniami barwników organicznych kraplaku i żywicznej gumigutty.

Poszczególne sceny skrzydeł ołtarzowych były ujęte w ramy, które zamykały zawarte w nich kompozycje. Na archiwalnej fotografii z 1907 roku kwatera ze sceną Ucieczki do Egiptu oprawiona jest w ramę, która - jak się wydaje - mogła pochodzić z rozebranego tryptyku²5.

${ }^{22}$ Na podstawie dolnej części szat św. Barbary oraz analogii do przedstawień św. Katarzyny wykonałam hipotetyczną rysunkową rekonstrukcję wizerunku św. Katarzyny, zob. Małgorzata Chmielewska, „Kulmbach's Saint Catherine of Alexandria from the Collection of the Czartoryski Museum in Krakow. Painting Conservation and Examination” (poster na konferencję $5^{\text {th }}$ Meeting X-ray and Other Techniques in Investigation of the Objects of Cultural Heritage, Uniwersytet Jagielloński, Kraków 2014).

23 Nad głową św. Katarzyny musiało widnieć łukowate zamknięcie okna podobne do tego, jakie można zobaczyć na archiwalnym zdjęciu, przedstawiającym obraz ze św. Barbarą znajdujący się przed 1939 r. w Pałacu pod Baranami w Krakowie.

24 W analizie spoiwa obok białka zidentyfikowany został olej schnący, przypuszczalnie dodany do tempery lub wykorzystany do naniesienia laserunkowej czerwieni zidentyfikowanej w próbce pobranej z partii czerwonej sukni.

25 Hola i Sitek, „Hans von Kulmbach,” 307. 
Porównując wyniki badań uzyskanych podczas konserwacji obrazu Św. Katarzyna Aleksandryjska z Muzeum Książąt Czartoryskich do analiz technologicznych sześciu obrazów z przedstawieniami scen z życia tej świętej ${ }^{26}$ opisanych w dokumentacji konserwatorskiej prac wykonanych w latach 2013-2015 dzięki wsparciu fundacji Getty Institute w Los Angeles, można zauważyć duże podobieństwo stosowanych materiałów. Podobrazia zarówno tryptyku maryjnego ${ }^{27}$, jak i cyklu obrazów ze św. Katarzyną Aleksandryjską wykonane zostały z drewna lipowego. Niewielkie różnice w sposobie przygotowania tablic malarskich mogły wynikać z faktu, iż skrzydła ołtarza ze Skałki były malowane obustronnie, dlatego jednakowo starannie zostały wykończone od strony awersu i rewersu. Wypełniaczem zapraw w przypadku wszystkich porównywanych obrazów jest kreda. W badaniach spoiwa we wszystkich dziełach zidentyfikowano białko, które wskazuje na użycie tempery, ale stwierdzono również obecność oleju, co pozwala przypuszczać, że obrazy zostały wykończone olejnymi laserunkami. Pigmenty, które zostały rozpoznane w badaniach, nie różnią się zasadniczo w porównywanych dziełach. Można przytoczyć przykłady zidentyfikowanych takich samych pigmentów z przypisaniem ich do podobnych elementów kompozycji. W partii nieba podstawowymi pigmentami rozpoznanymi w badaniach jest biel ołowiowa i azuryt, w przedstawieniu szaty św. Katarzyny - cynober i czerwień organiczna, która w próbce pobranej z obrazu św. Katarzyny Aleksandryjskiej została uściślona jako kraplak. Wspólny dla tych dzieł jest także pigment żółty, czyli żółcień cynowo-ołowiowa. Istotną różnicę stanowi rozpoznanie w obrazach z kościoła Mariackiego warstwy imprimitury wykonanej właśnie żółcienią cynowo-ołowiową. W przedstawieniu z Muzeum Książąt Czartoryskich pomiędzy zaprawą a malowidłem występuje jedynie cienka warstwa kleju, pełniąca prawdopodobnie funkcję izolacyjną, a przez swój lekko złotobrązowy kolor jednocześnie ocieplająca odcień białego gruntu.

26 Badania i konserwacja zostały przeprowadzone w ramach programu „The Panel Painting Project'” finansowanego przez Getty Institute z Los Angeles, zob. Aleksandra Hola et al., „Badania sześciu obrazów Hansa Süssa z Kulmbachu przedstawiających sceny z życia św. Katarzyny Aleksandryjskiej,” w Jako serce pośrodku ciała... Kultura artystyczna kościoła Mariackiego w Krakowie, red. Marek Walczak i Agata Wolska (Kraków: Bazylika Mariacka w Krakowie / Wydawnictwo Towarzystwa Naukowego Societas Vistulana, 2020-2021), 393-397.

27 Środkowa część tryptyku, przedstawiająca Pokłon Trzech Króli, namalowana jest na podobraziu lipowym, podobnie jak obraz Św. Katarzyna Aleksandryjska, zob. Sitek, „'Uczeń Dürera w Polsce'," 40. 
Ważnym elementem badań towarzyszących pracom konserwatorskim było rozpoznanie i udokumentowanie zakresu konserwacji przeprowadzonej przez Aloisa Hausera Młodszego. Prześwietlenie obrazu promieniami rentgenowskimi pozwoliło ocenić stan zachowania oryginalnego podobrazia, a także dodanej przez konserwatora konstrukcji (il. 12). Hauser osadził obraz wewnątrz dodatkowego, większego podłoża, wykonanego z drewna topolowego $^{28}$, starannie wklejając go w wyciętą w nowej desce owalną płycinę. Ten zabieg znacznie wzmocnił cienkie ${ }^{29}$ deski podobrazia, a ponadto sprawił, że obrazowi nadany został kształt prostokąta, bardziej zgodny z pierwotną kompozycją skrzydła ołtarzowego. W celu zwiększenia stabilności podwojonej tablicy konserwator zastosował tzw. parkietaż, czyli kratownicę z naklejonymi na rewers czterema pionowymi listwami o zróżnicowanej szerokości mającymi otwory umożliwiające wsunięcie w nie pięciu ruchomych listew poziomych (il. 13). Prace przy podobraziu objęły także zaślepienie otworów wylotowych po owadach drewnianymi kołeczkami. Na zlicowaną z obrazem powierzchnię dodanej deski topolowej Hauser naniósł białą zaprawę kredowo-klejową i szpachlą zatarł zaprawę na krawędziach owalu, aby jak najlepiej zgubić ślad łączenia oryginału z zaplanowaną wokół niego rekonstrukcją. Bardzo dokładnie oczyścił zabrudzoną warstwę malarską, usuwając stare retusze i przemalowania, pozostawił natomiast niektóre wcześniejsze kity. Być może przy oczyszczaniu zmył częściowo laserunki ${ }^{30}$, co mogło spowodować późniejsze pretensje współczesnej mu Konstancji Stępowskiej o zbytnie uwydatnienie białych świateł wokół ust i oczu, co miało nieco zmienić wyraz twarzy namalowanej postaci ${ }^{31}$. Wyretuszował drobne ubytki warstwy malarskiej, usytuowane głównie wzdłuż łączenia desek. Rekonstrukcje uzupełniające kompozycję w obrębie nowego podłoża Hauser wykonał z dużą wrażliwością, idealnie imitując styl Kulmbacha. Niemiecki konserwator zatroszczył się również o oprawę powiększonego obrazu, wykorzystując ramę o prostym listwowym profilu, polichromowaną czarną temperą z malowanym ornamentem

28 Identyfikację dendrologiczną przeprowadził mgr Jan Ptak w Zakładzie Materiałoznawstwa oraz Historii Technik Dzieł Sztuki WKiRDS ASP w Krakowie.

29 Grubość podobrazia wynosi ok. 0,3-0,4 cm.

30 Marian Sokołowski pisał o „radykalnej konserwacji” obrazu Pokłon Trzech Króli z Berlina, wykonanej przez Hausera: Marian Sokołowski, „Sprawozdanie z posiedzeń Komisyi Historyi Sztuki w dniu 20.II.1902," Sprawozdania Komisji do Badań Historii Sztuki 8, z. 1-2 (1907): szp. VII.

31 Stępowska, „Przyczynki,” szp. XX, przyp.1. 
w złotym kolorze ${ }^{32}$ (il. 14). Ani na obrazie, ani na ramie nie odnaleziono sygnatury Hausera, pomimo że - jak podaje Jerzy Żmudziński ${ }^{33}$ - firmował on swoje prace, o czym świadczą informacje zawarte w jego listach.

Wykonana w pracowni Hausera konstrukcja podwójnego podobrazia skutecznie zabezpieczyła delikatne, cienkie podłoże obrazu i pozwoliła mu przetrwać w stosunkowo dobrym stanie wojenne transporty do kolejnych magazynów, gdzie składowano najcenniejsze zabytki z polskich zbiorów zarekwirowane przez niemieckich okupantów ${ }^{34}$. Przez prawie sto lat od zakończenia berlińskiej konserwacji obraz nie wymagał poważniejszych zabiegów. Jak wynika z archiwalnych kart muzealnej pracowni konserwatorskiej, podejmowane były jedynie doraźne działania, obejmujące głównie podklejanie drobnych odspojeń warstwy malarskiej powstających przy zmianach warunków klimatycznych i powierzchowne oczyszczanie oraz dodawanie warstw werniksów i retuszy. Gdy obraz trafił do pracowni konserwacji w 1999 roku, jego stan techniczny był - poza nielicznymi odpryskami warstwy malarskiej - stosunkowo dobry. Pozytywnie oceniono stabilizujące działanie zastosowanego przez Hausera wzmocnienia desek podobrazia na stan zachowania malowidła. W odpowiednich warunkach wilgotnościowych podłoże jest wystarczająco stabilne, dlatego formułując założenia konserwatorskie nie brano pod uwagę tak drastycznej dla obiektu zmiany, jaką byłby demontaż wprowadzonych wcześniej elementów. Najmniej odporne na działanie upływającego czasu okazały się retusze i rekonstrukcje wykonane farbami olejnymi ${ }^{35}$. Na tle jasnozielonkawej fluorescencji wzbudzonej promieniowaniem ultrafioletowym były one wyraźnie widoczne w postaci licznych ciemniejszych plam w części centralnej i jednolicie ciemniejszego prostokątnego obramienia - rekonstrukcji (il. 15). Stopniowe ciemnienie malowidła, spowodowane

32 Rama została przycięta i dopasowana do wymiarów obrazu, nosi ślady drobnych prac renowacyjnych (kity i poprawki przetartego ornamentu). Datowanie tej ramy wymaga dalszych ustaleń.

33 Żmudziński, „Restauracja zabytków malarstwa sztalugowego,” 191-192.

34 Na rewersie obrazu zachowała się charakterystyczna naklejka z odręcznie naniesionym numerem i podpisem pochodząca z czasu rekwizycji obrazu do magazynu utworzonego przez władze okupacyjne w gmachu Biblioteki Jagiellońskiej. Wojenne podróże obrazów Kulmbacha szczegółowo przedstawili Agata Wolska i Wojciech Walanus, „Wojenne i powojenne losy krakowskich dzieł Hansa Suessa z Kulmbachu,” w Mistrz i Katarzyna, 227-253.

35 Zidentyfikowano m.in. błękit pruski i żółcień chromową, które potwierdzają datowanie retuszy i rekonstrukcji. Badania zostały wykonane metodami mikroskopowymi i mikrochemicznymi przez dr. Pawła Karaszkiewicza w Zakładzie Chemii Konserwatorskiej WKiRDS ASP w Krakowie. 
wprowadzeniem wosku przy podklejaniu łusek warstwy malarskiej, oraz żółknięcie zastosowanych werniksów częściowo maskowało różnicę pomiędzy oryginałem a późniejszą rekonstrukcją ${ }^{36}$.

W toku oczyszczania obrazu okazało się, że retusze niejednokrotnie wychodzą poza krawędzie ubytków, a niektóre partie obrazu, takie jak fragment nieba albo rękaw świętej, są częściowo przemalowane. Werniksy usuwano mieszaniną acetonu, etanolu i terpentyny, jednocześnie podklejając odspojoną miejscami warstwę malarską 3-procentowym klejem króliczym. Po odsłonięciu namalowanej w technice tempery, świetlistej oryginalnej warstwy malarskiej różnica w porównaniu z wykonanymi olejno uzupełnieniami Hausera była trudna do zaakceptowania (il. 16). Z tego powodu, pomimo niewątpliwych walorów, rekonstrukcje te po sfotografowaniu zostały w całości usunięte dimetyloformamidem neutralizowanym terpentyną. W obrębie podobrazia jedyną konieczną do wykonania ingerencją była niewielka korekta długości kołeczków użytych do zaślepienia otworów po owadach, które nieznacznie uwidoczniły się na licu obrazu. Po ścięciu wystających ponad lico deski fragmentów zostały one zaimpregnowane 10-procentowym roztworem Paraloidu B 72 w toluenie.

Po odjęciu wszystkich nawarstwień przy krawędzi owalu po prawej stronie uwidocznił się niewielki doklejony fragment deski pochodzącej z innego obrazu. Wątpliwości dotyczące tego skrajnego odcinka owalu częściowo wyjaśniły wyniki badań identyfikujących użyte do jego wykonania materiały. Potwierdziły one jednoznacznie, że znajdujące się na nim resztki warstwy malarskiej są pozostałościami zupełnie innego obrazu (il. 17). Co prawda malowidło to powstało na podłożu podobnym do tego, na którym namalowano św. Katarzynę ${ }^{37}$, lecz widniejąca na nim nierozpoznawalna w tak wąskim fragmencie kompozycja została wykonana w technice olejno-żywicznej, a zidentyfikowane pigmenty różnią się od stosowanych przez Kulmbacha. W badaniach próbek pobranych z tego fragmentu potwierdzono użycie smalty, indygo, bieli ołowiowej i cynobru, co skłania do przypuszczenia, że obraz ów mógł powstać w XVII lub XVIII wieku. Być może wykonanie tej wstawki

36 Prof. Maria Niedzielska, konserwator i pedagog krakowskiej ASP oraz autorytet zarówno w dziedzinie technologii malarstwa, jak i konserwacji, postrzegała obraz jako dzieło w całości ręki Kulmbacha. Przekaz ustny uzyskany podczas rozmowy w trakcie obrad komisji dotyczącej obrazu Kulmbacha w Pracowni Konserwacji Muzeum Książąt Czartoryskich w 1999 r.

37 Stwierdzono użycie deski lipowej. Identyfikację dendrologiczną przeprowadził mgr Jan Ptak w Zakładzie Materiałoznawstwa oraz Historii Technik Dzieł Sztuki WKiRDS ASP w Krakowie. 
wiązało się z konserwacją przeprowadzoną po rozdzieleniu obrazów ${ }^{38}$ składających się na maryjne retabulum.

Jak już wspomniano wyżej, podstawowym założeniem konserwacji estetycznej było wyeksponowanie wyłącznie oryginalnego dzieła Kulmbacha, dlatego uzupełnienia zaprawy i warstwy malarskiej wykonano jedynie w partii oryginału, stosując kit kredowo-klejowy, akwarele, werniks mastyksowy oraz odsączone z oleju farby ze spoiwem żywicznym. Powierzchnię wstawki doklejonej z fragmentu innego obrazu pokryto białą zaprawą kredowo-klejową, a następnie kolorem nawiązującym do świetlistego pejzażu, założonym w technice akwarelowej. Lico malowidła po zakończonych zabiegach zabezpieczono werniksem ketonowym z woskiem mikrokrystalicznym. Pozostawienie wzmacniającej podobrazie prostokątnej deski wymagało zaprojektowania nowej aranżacji całości. Surowe, nienadające się do eksponowania drewno uzupełnionych przez Hausera partii podobrazia zasłoniła odpowiednio wyprofilowana nakładka wykonana z drewna dębowego ${ }^{39}$. Niestety rama, w którą obraz został oprawiony przez Hausera okazała się zbyt płytka i wąska, aby zmieścić w niej całość dzieła po wprowadzonych zmianach. Zaprojektowano i wykonano więc nową oprawę, nawiązującą do renesansowych ram z galerii malarstwa Muzeum Książąt Czartoryskich, z kasetonowym profilem, zdobioną dekoracją w technice sgraffito (il. 18). Po zakończonej konserwacji obraz odzyskał blask, utracony częściowo w wyniku upływu czasu i związanych z tym procesów „starzenia” się materiałów. Nowy sposób oprawy i ekspozycji, pomimo wprowadzonych zmian, częściowo zachował elementy poprzednich konserwacji, świadczące o jego historii.

Losy obrazów Kulmbacha, których pochodzenie łączone jest z tryptykiem, były bardzo różne, co niewątpliwie miało wpływ na stan, w jakim dotrwały one do naszych czasów. Wydaje się, że największe znaczenie dla stanu zachowania, oprócz warunków przechowywania, miały niekorzystne zmiany wynikające z działań podjętych przy okazji kolejnych renowacji. Zestawiając wizerunek św. Katarzyny oraz Ucieczkę do Egiptu i dolną część postaci św. Barbary znajdującej się na rewersie tej sceny można zauważyć, że ten ostatni fragment był w mniejszym stopniu przekształcany, podczas gdy zarówno przedstawienie św. Katarzyny, jak i Ucieczka do Egiptu były kilkakrotnie

38 Nieusunięte przez Aloisa Hausera ciemnobrązowe kity pochodzą prawdopodobnie z wcześniejszej konserwacji obrazu.

39 Prace stolarskie zostały wykonane w Muzeum Narodowym w Krakowie przez Stanisława Słotę. 
konserwowane. Ich powierzchnie były czyszczone i przemalowywane olejnymi farbami, co nie pozostawało bez wpływu na strukturę i kondycję warstwy malarskiej. Sfałdowane szaty i stopy św. Barbary nie mogły być uznane za samodzielny obraz, który nadawałby się do ekspozycji, dlatego te części skrzydeł nie zostały rozcięte, zachowując cenne informacje dotyczące ich grubości i budowy podobrazia. Od czasu podzielenia ołtarza fragment ten raczej nie był poddawany większym zabiegom konserwatorskim, malowidło nie było czyszczone, przemalowywane ani poprawiane. Paradoksalnie zatem, być może ta „niechciana”, „nieatrakcyjna” część podzielonego tryptyku mogłaby powiedzieć nam jeszcze nieco więcej o technice malarskiej mistrza. Być może w przyszłości podjęte zostaną prace badawcze nad tym fragmentem, co byłoby z pewnością cennym uzupełnieniem dotychczasowych ustaleń. 


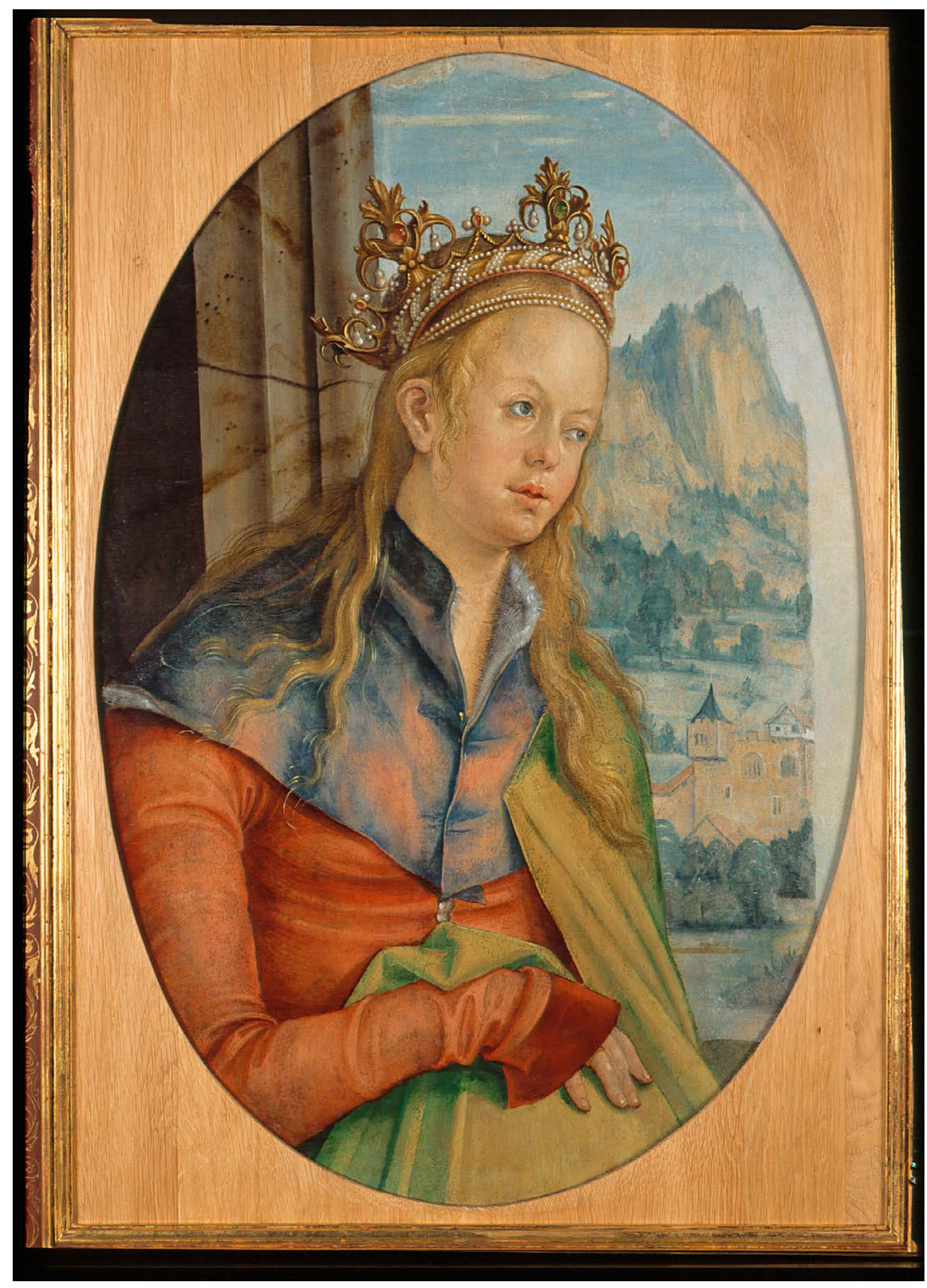

Il. 1. Hans Süss von Kulmbach, Św. Katarzyna, ok. 1511, tempera / deska, 56,0 × 38,2 cm, Muzeum Narodowe w Krakowie - Muzeum Książąt Czartoryskich. Obraz po konserwacji. Fot. Fundacja Książąt Czartoryskich 


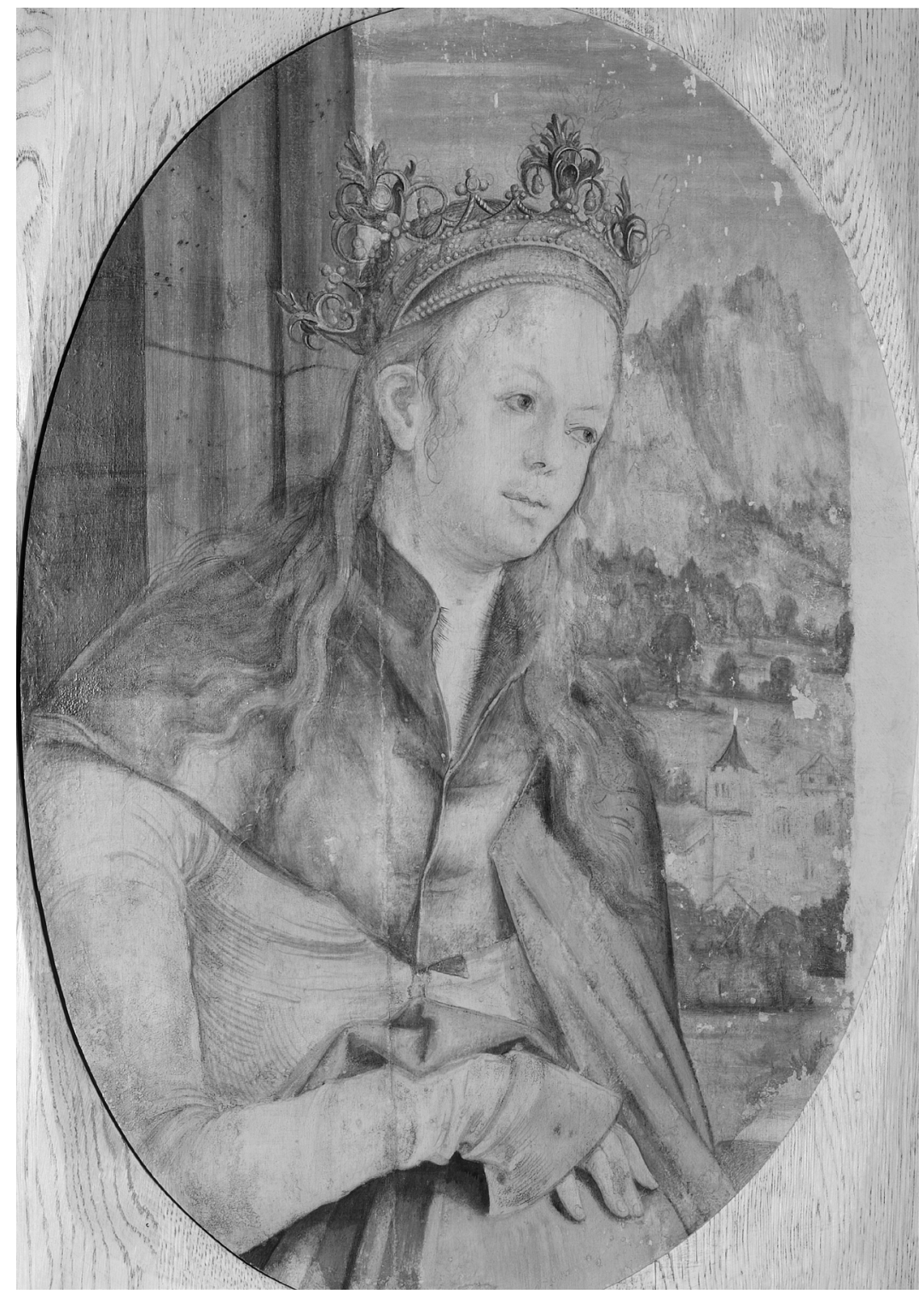

Il. 2. Hans Süss von Kulmbach, Św. Katarzyna, ok. 1511, Muzeum Narodowe w Krakowie - Muzeum Książąt Czartoryskich. Fotografia w bliskiej podczerwieni, czytelny rysunek przygotowawczy. Fot. P. Frączek, M. Obarzanowski 


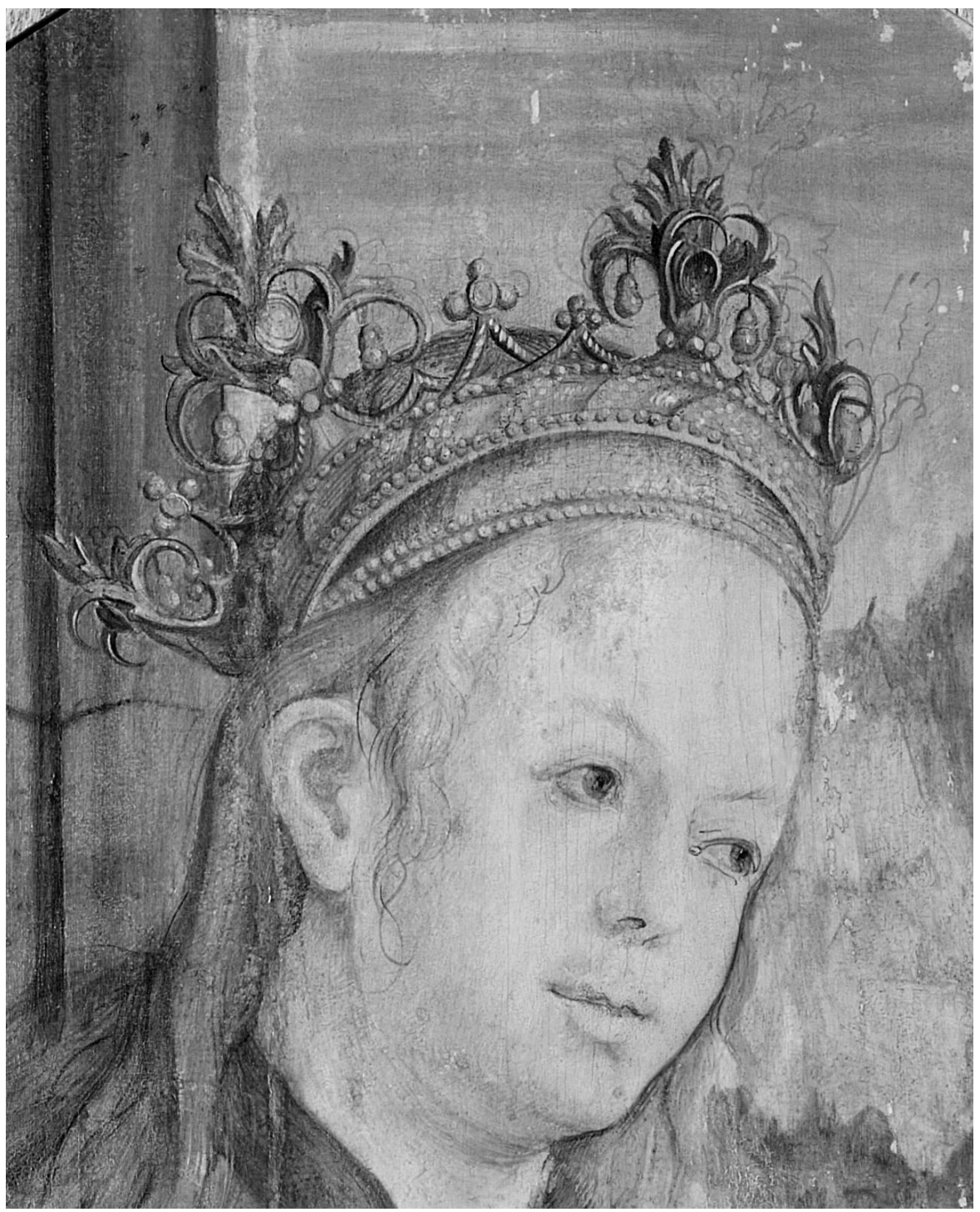

Il. 3. Hans Süss von Kulmbach, Św. Katarzyna, ok. 1511, Muzeum Narodowe w Krakowie - Muzeum Książąt Czartoryskich. Fragment zdjęcia w bliskiej podczerwieni - widoczne pentimenti w partii korony. Fot. P. Frączek, M. Obarzanowski 


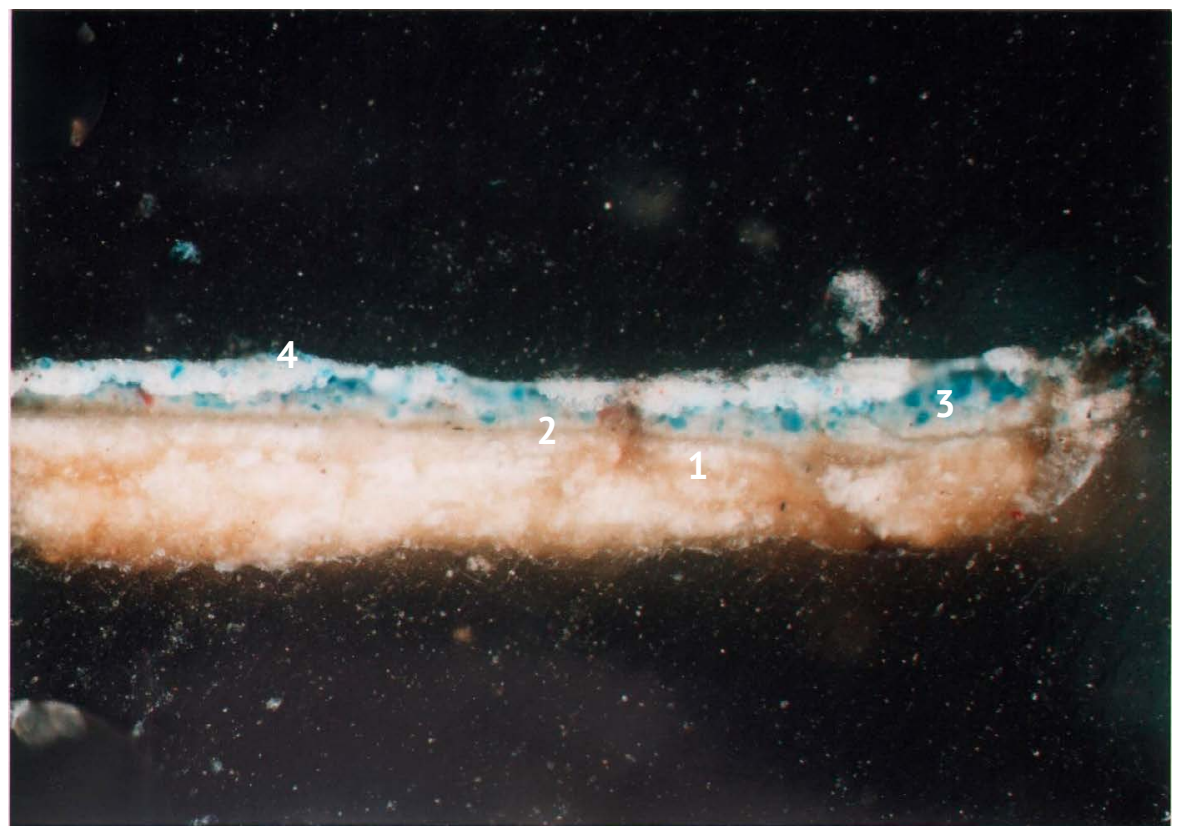

Il. 4. Hans Süss von Kulmbach, Św. Katarzyna, ok. 1511, Muzeum Narodowe w Krakowie - Muzeum Książąt Czartoryskich. Przekrój boczny warstw technologicznych, próbka pobrana z partii nieba. Fot. M. Rogóż

1 - biała zaprawa wielowarstwowa, 2 - cienka warstwa brązowego kleju, 3 - warstwa bieli z wtrąceniami azurytu, 4 - warstwa przemalowania 


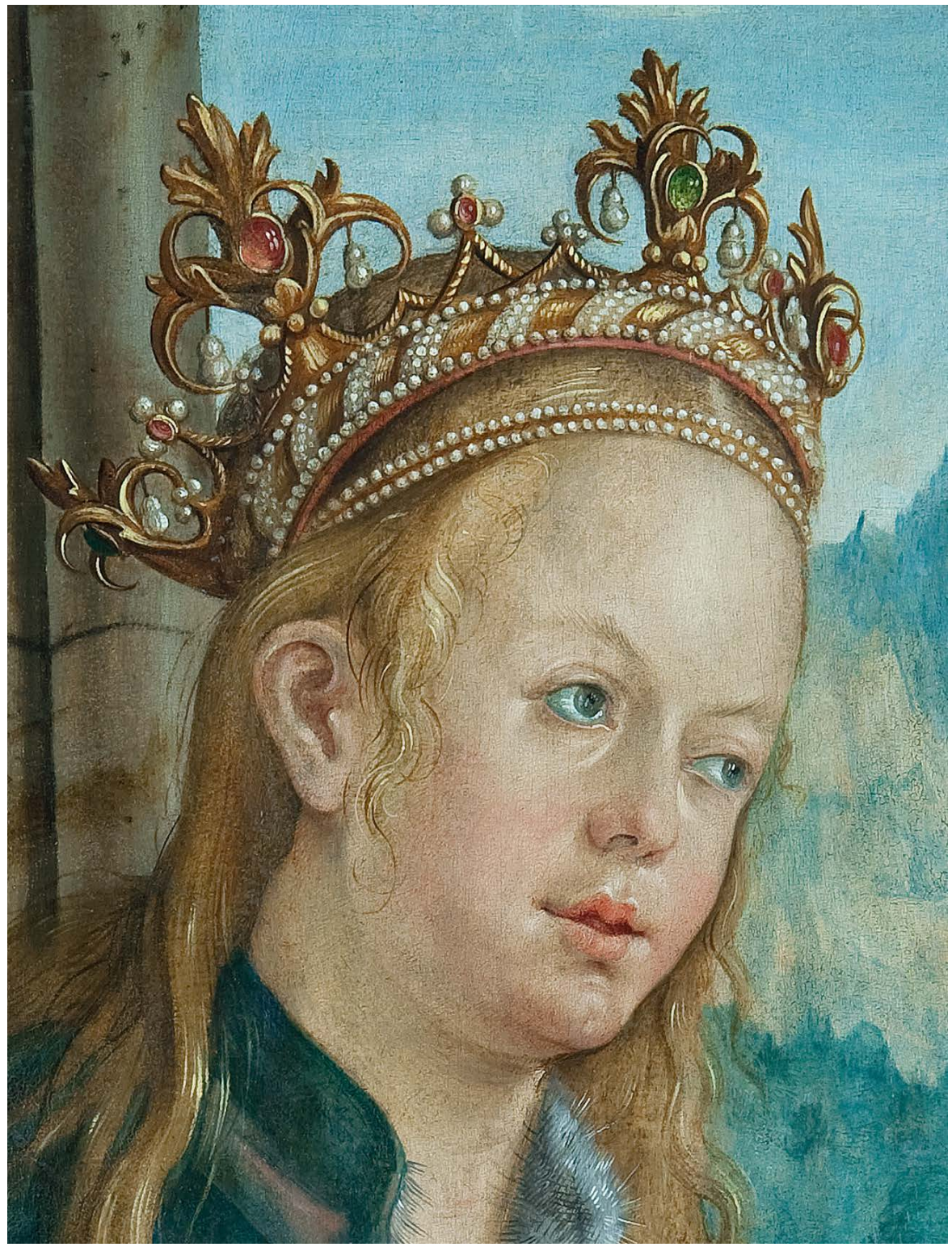

Il. 5. Hans Süss von Kulmbach, Św. Katarzyna, ok. 1511, Muzeum Narodowe w Krakowie - Muzeum Książąt Czartoryskich. Fragment - twarz postaci. Fot. M. Chmielewska 


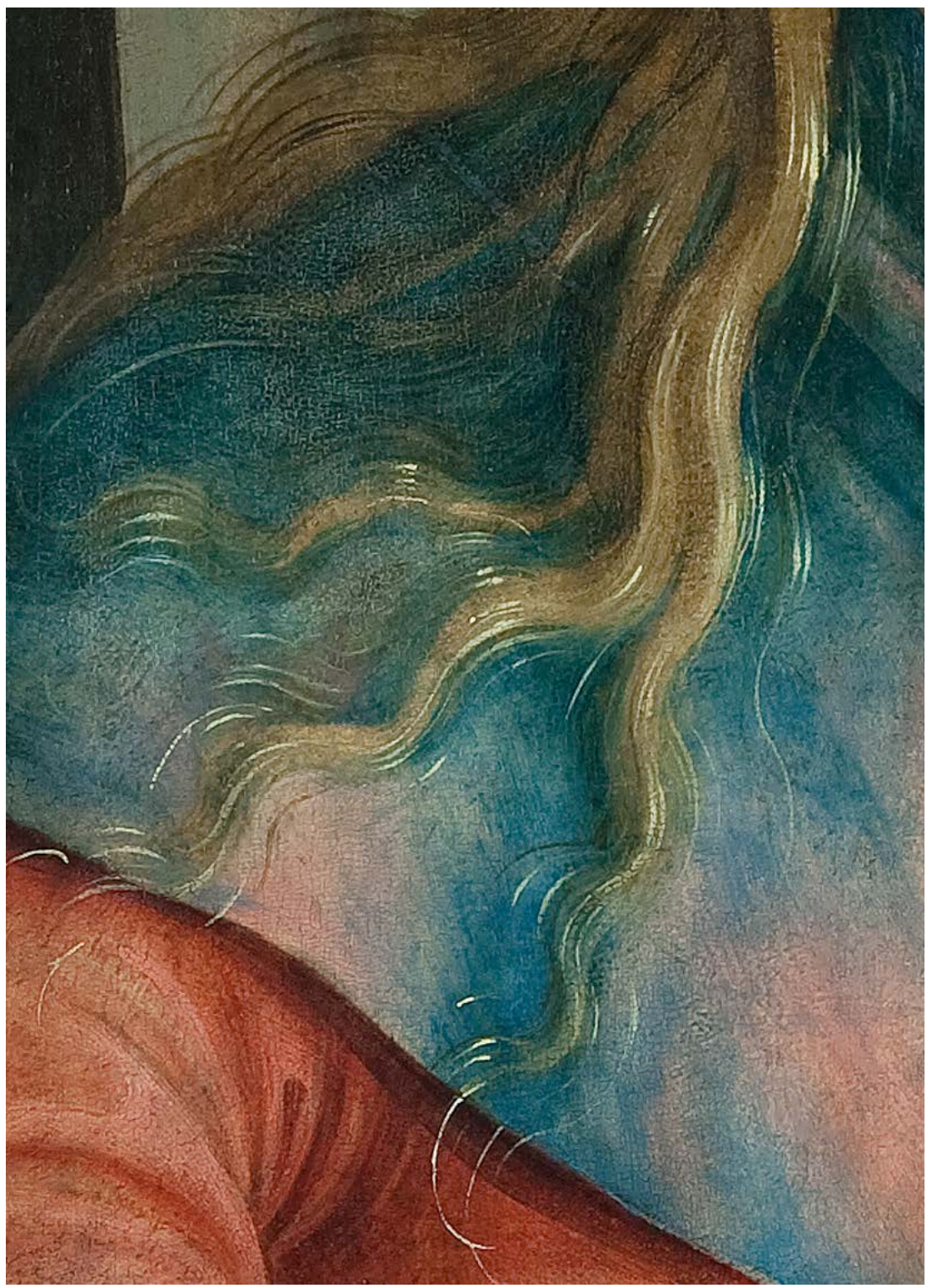

Il. 6. Hans Süss von Kulmbach, Św. Katarzyna, ok. 1511, Muzeum Narodowe w Krakowie - Muzeum Książąt Czartoryskich. Fragment - opracowanie włosów i kołnierza. Fot. M. Chmielewska 


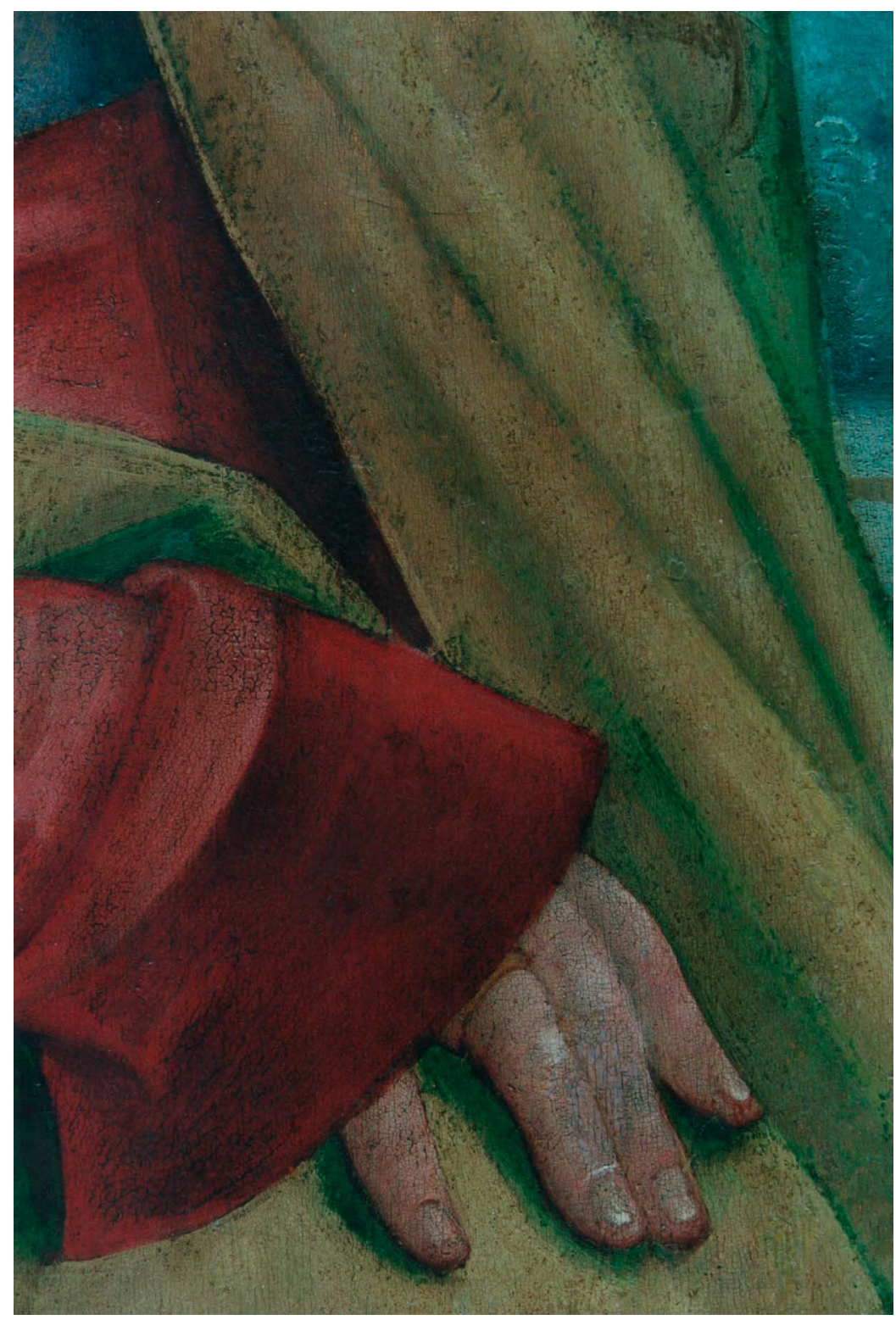

Il. 7. Hans Süss von Kulmbach, Św. Katarzyna, ok. 1511, Muzeum Narodowe w Krakowie - Muzeum Książąt Czartoryskich. Fragment - opracowanie szat i dłoni. Fot. M. Chmielewska 


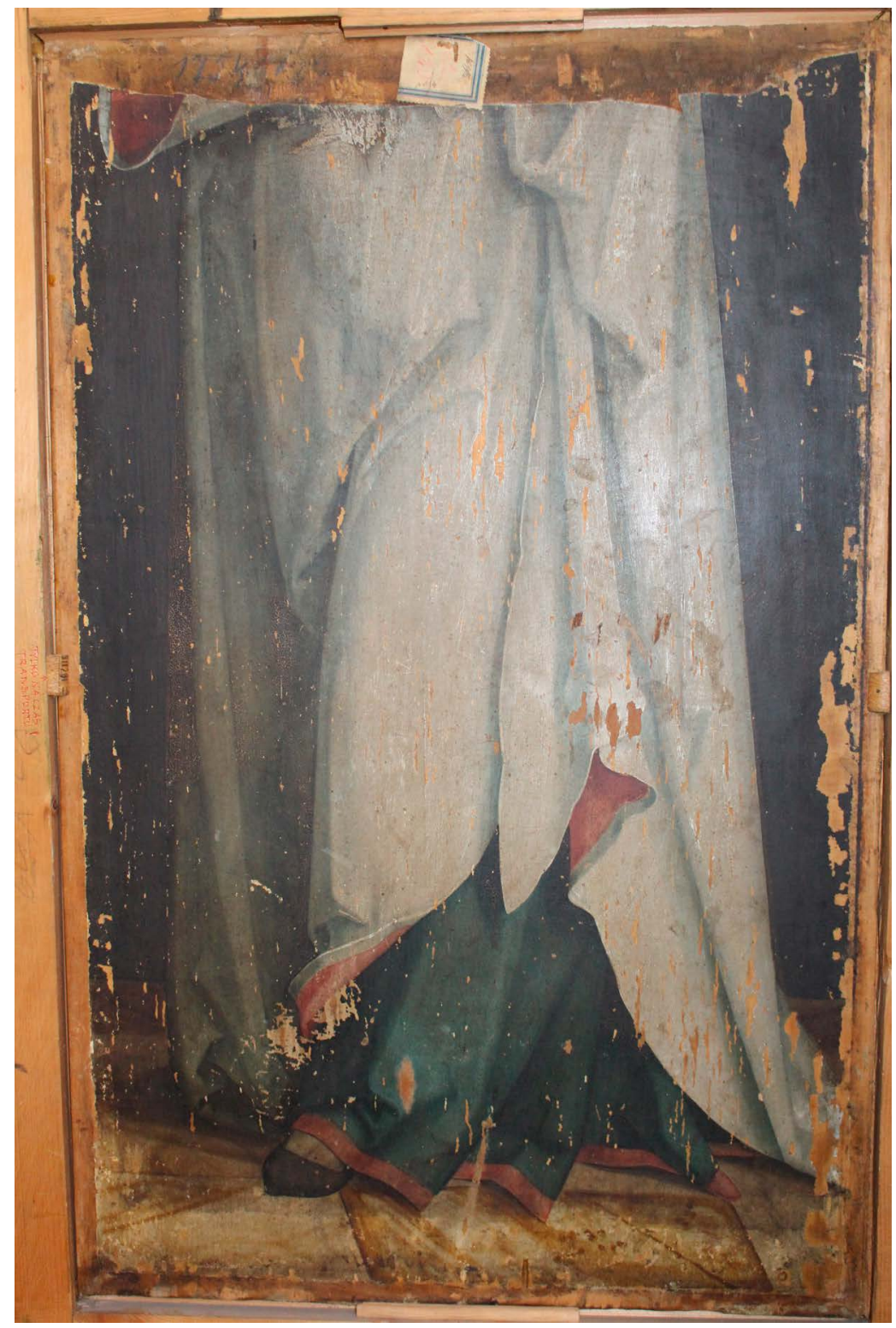

Il. 8. Hans Süss von Kulmbach, zachowany fragment przedstawienia św. Barbary na rewersie Ucieczki do Egiptu, ok. 1511, tempera / deska, $52 \times 81 \mathrm{~cm}$, Muzeum Narodowe w Krakowie - Muzeum Książąt Czartoryskich. Fragment szat św. Barbary. Fot. M. Chmielewska 


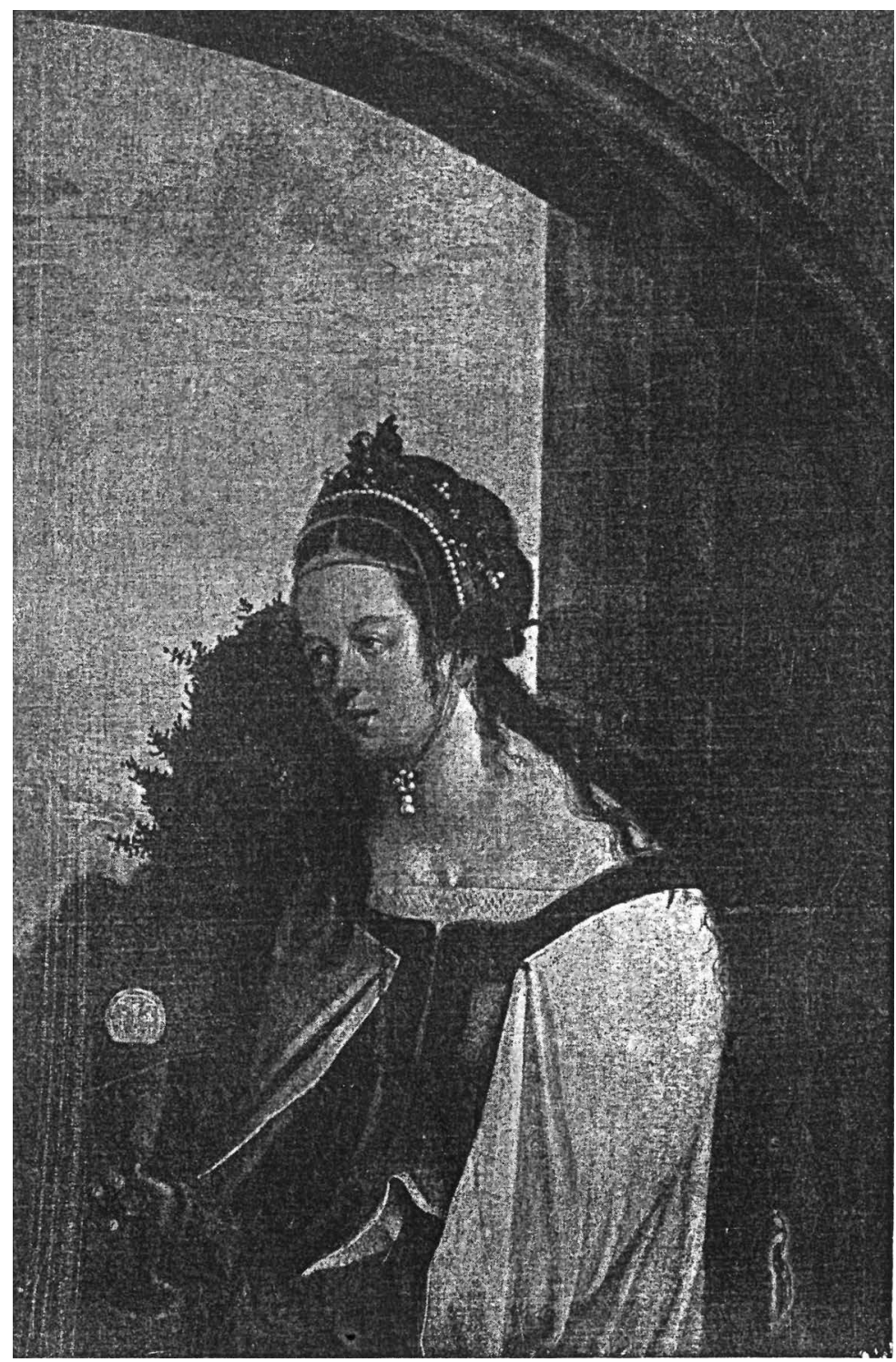

Il. 9. Hans Süss von Kulmbach, Św. Barbara, ok. 1511, Muzeum Narodowe w Krakowie - Muzeum Książąt Czartoryskich. Fragment - popiersie świętej. Fot. archiwalna. Źródło: M. Sokołowski, „Sprawozdania z posiedzeń Komisyi Historyi Sztuki w dniu 20.II.1902," Sprawozdania Komisji do Badań Historii Sztuki 8, z. 1-2 (1907): szp. XVIII, fig. 9 


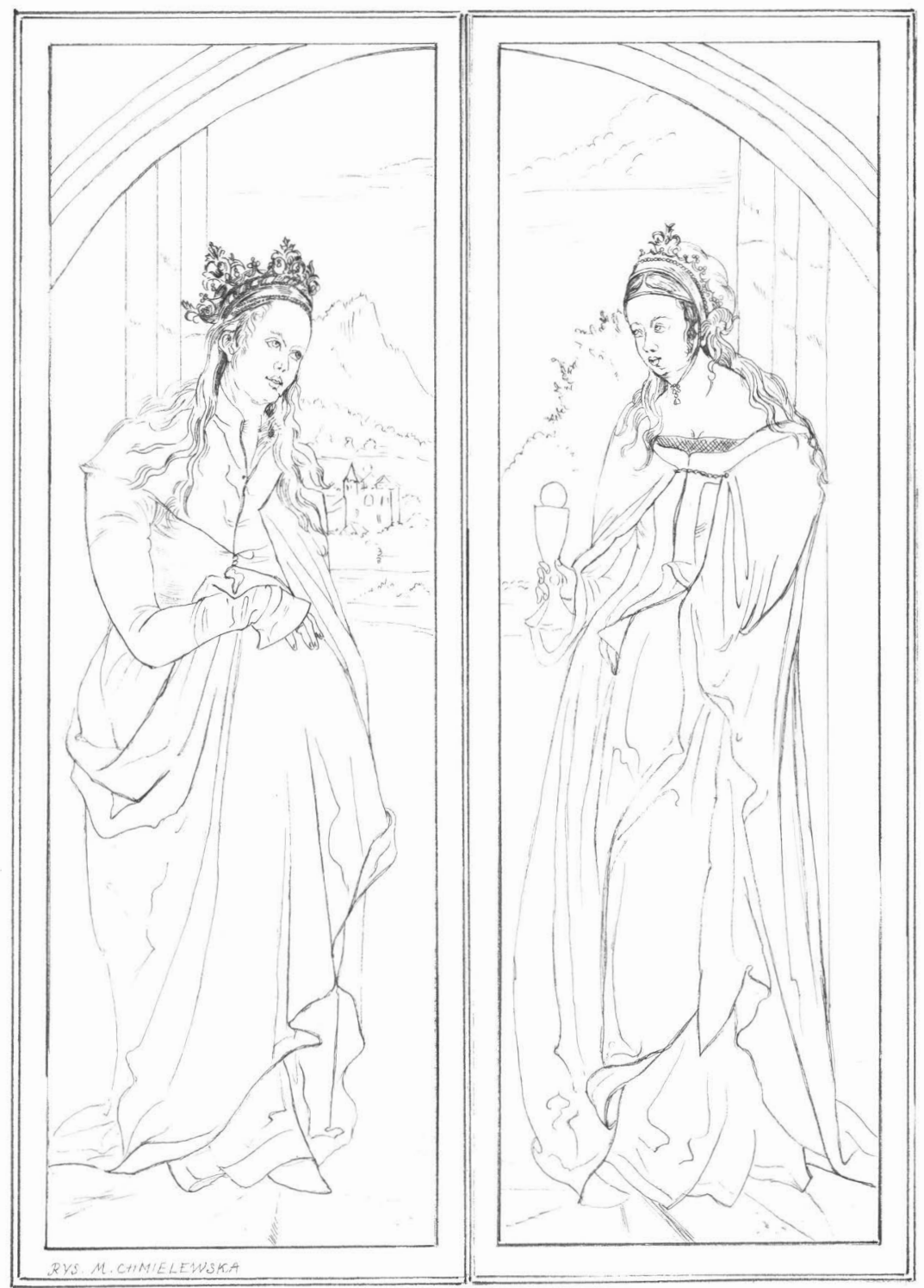

Il. 10. Hipotetyczna rysunkowa rekonstrukcja zamkniętego ołtarza z przedstawionymi na rewersach skrzydeł wizerunkami św. Katarzyny i św. Barbary. Rys. M. Chmielewska 


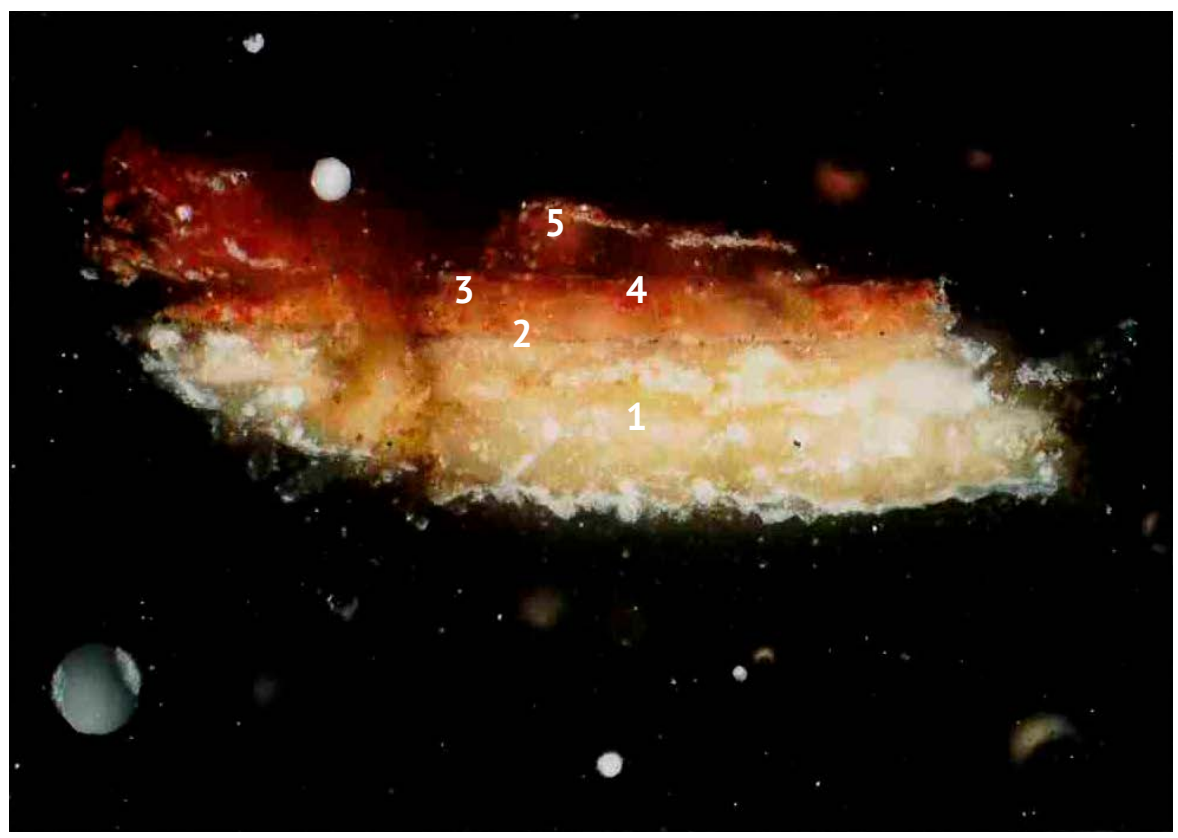

Il. 11. Hans Süss von Kulmbach, Św. Katarzyna, ok. 1511, Muzeum Narodowe w Krakowie - Muzeum Książąt Czartoryskich. Przekrój boczny warstw technologicznych, próbka pobrana z partii czerwonej sukni św. Katarzyny. Fot. M. Rogóż

1 - biała zaprawa wielowarstwowa, 2 - cienka warstwa kleju, 3 - warstwa czerwieni rozbielona z wtrąceniami czerni, 4 - cienka warstwa izolacyjna, 5 - warstwa ciemniejszej czerwieni, 6 - warstwa czerwieni laserunkowej 


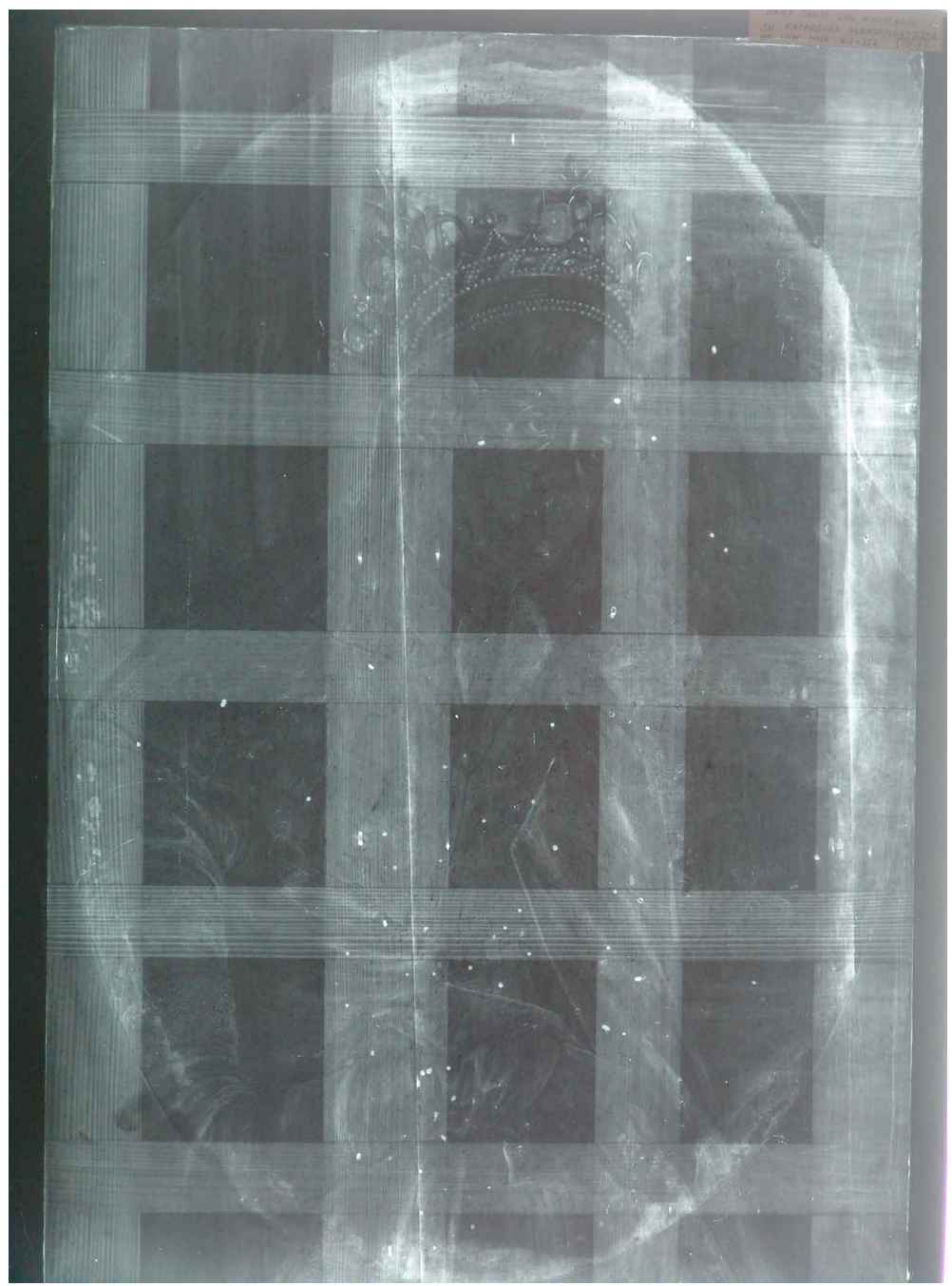

Il. 12. Hans Süss von Kulmbach, Św. Katarzyna, ok. 1511, Muzeum Narodowe w Krakowie - Muzeum Książąt Czartoryskich. Rentgenogram. Fot. J. Rutkowski 


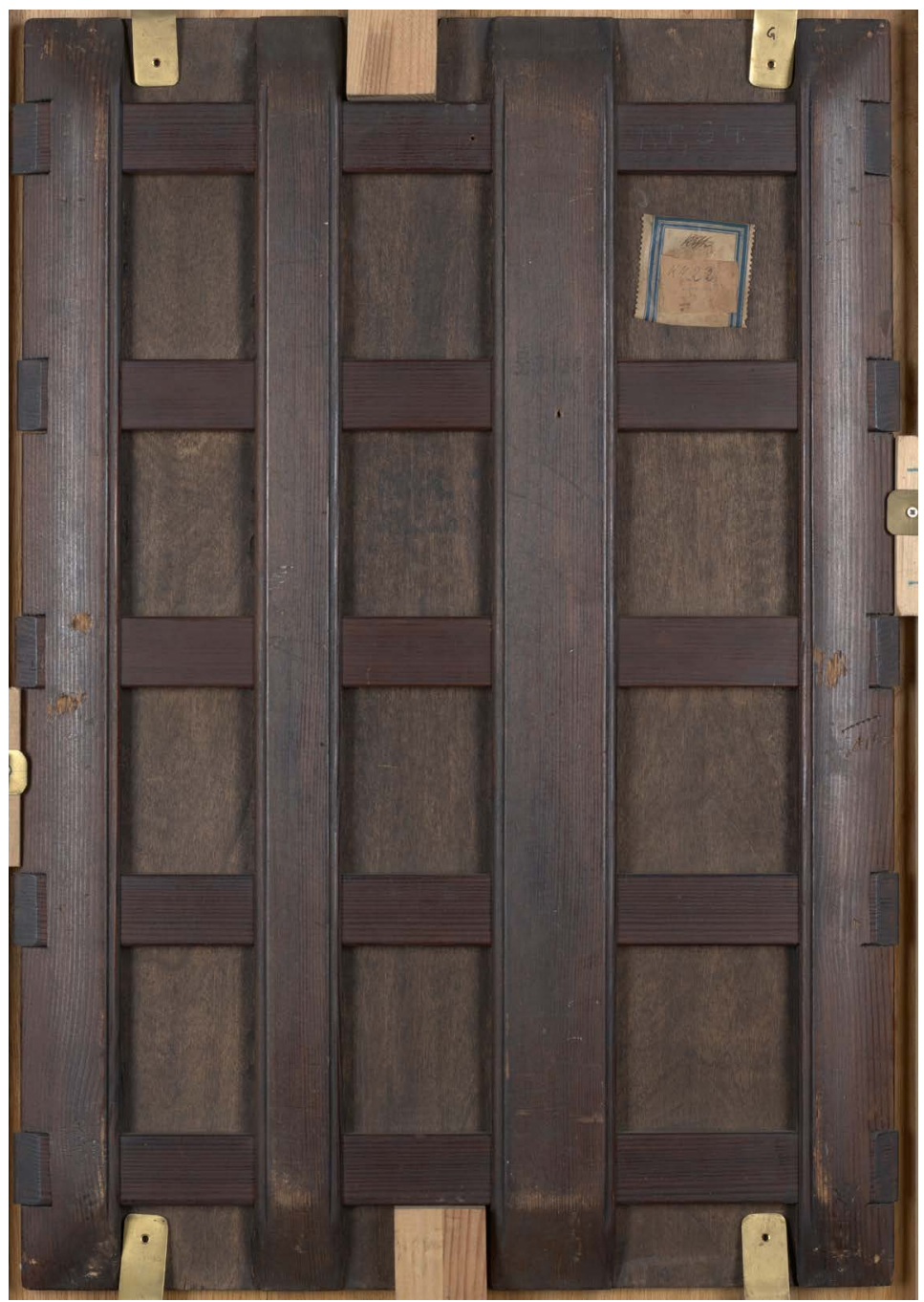

Il.13. Hans Süss von Kulmbach, Św. Katarzyna, ok. 1511, Muzeum Narodowe w Krakowie - Muzeum Książąt Czartoryskich. Odwrocie obrazu. Fot. Fundacja Książąt Czartoryskich 


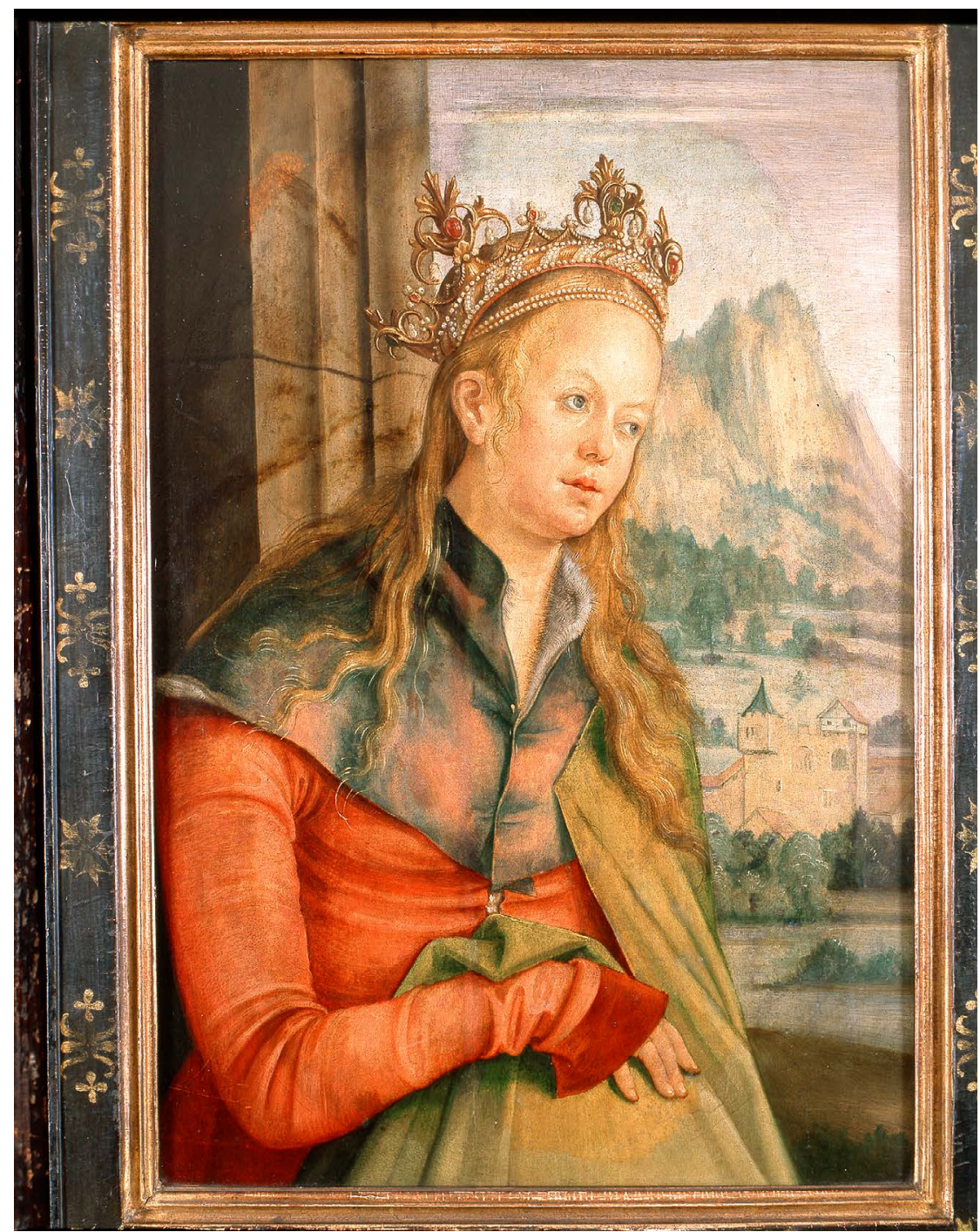

Il. 14. Hans Süss von Kulmbach, Św. Katarzyna, ok. 1511, Muzeum Narodowe w Krakowie Muzeum Książąt Czartoryskich. Stan przed konserwacją-restauracją. Fot. Fundacja Książąt Czartoryskich 


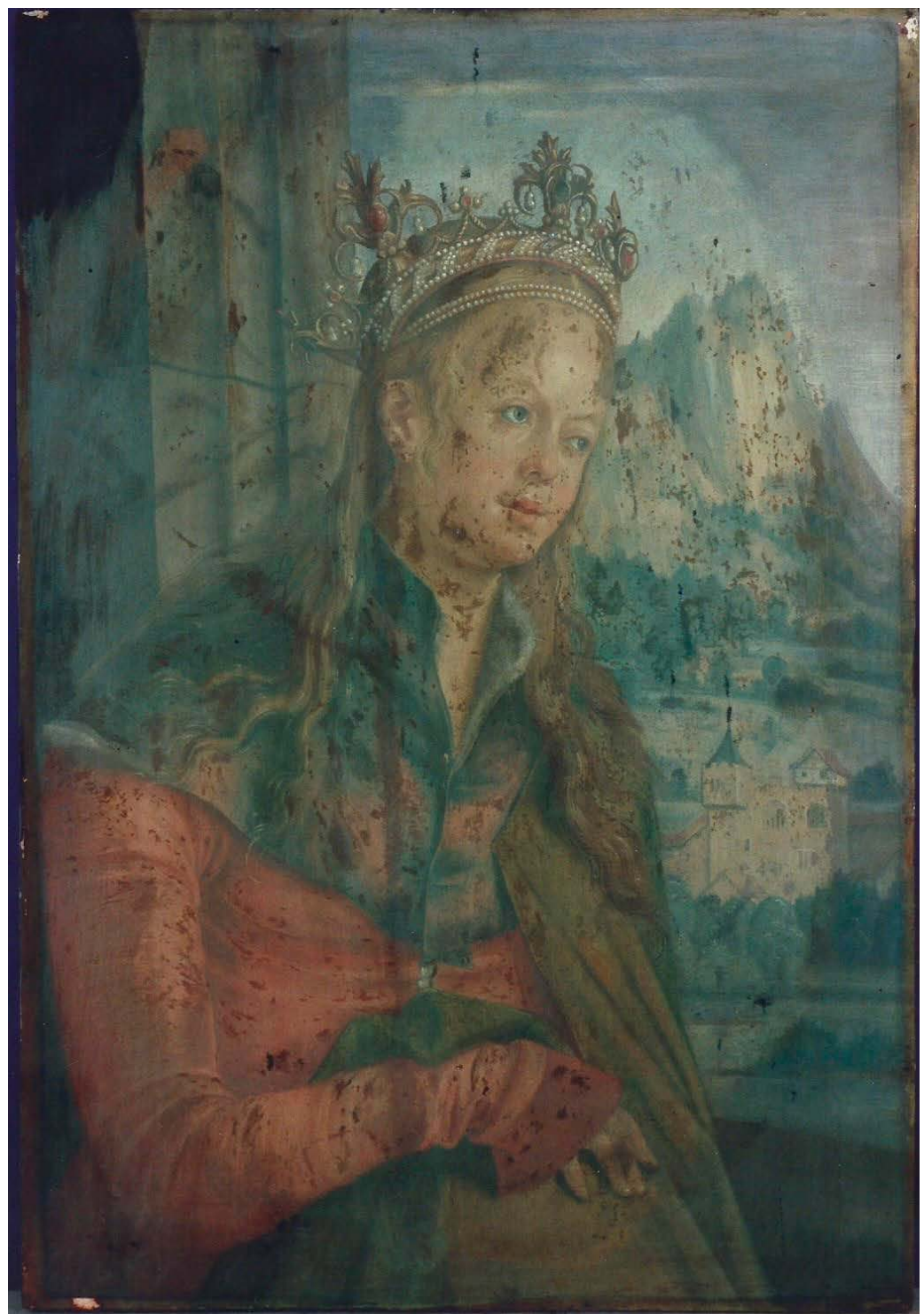

Il. 15. Hans Süss von Kulmbach, Św. Katarzyna, ok. 1511, Muzeum Narodowe w Krakowie - Muzeum Książąt Czartoryskich. Fluorescencja wzbudzana UV. Fot. J. Rutkowski 


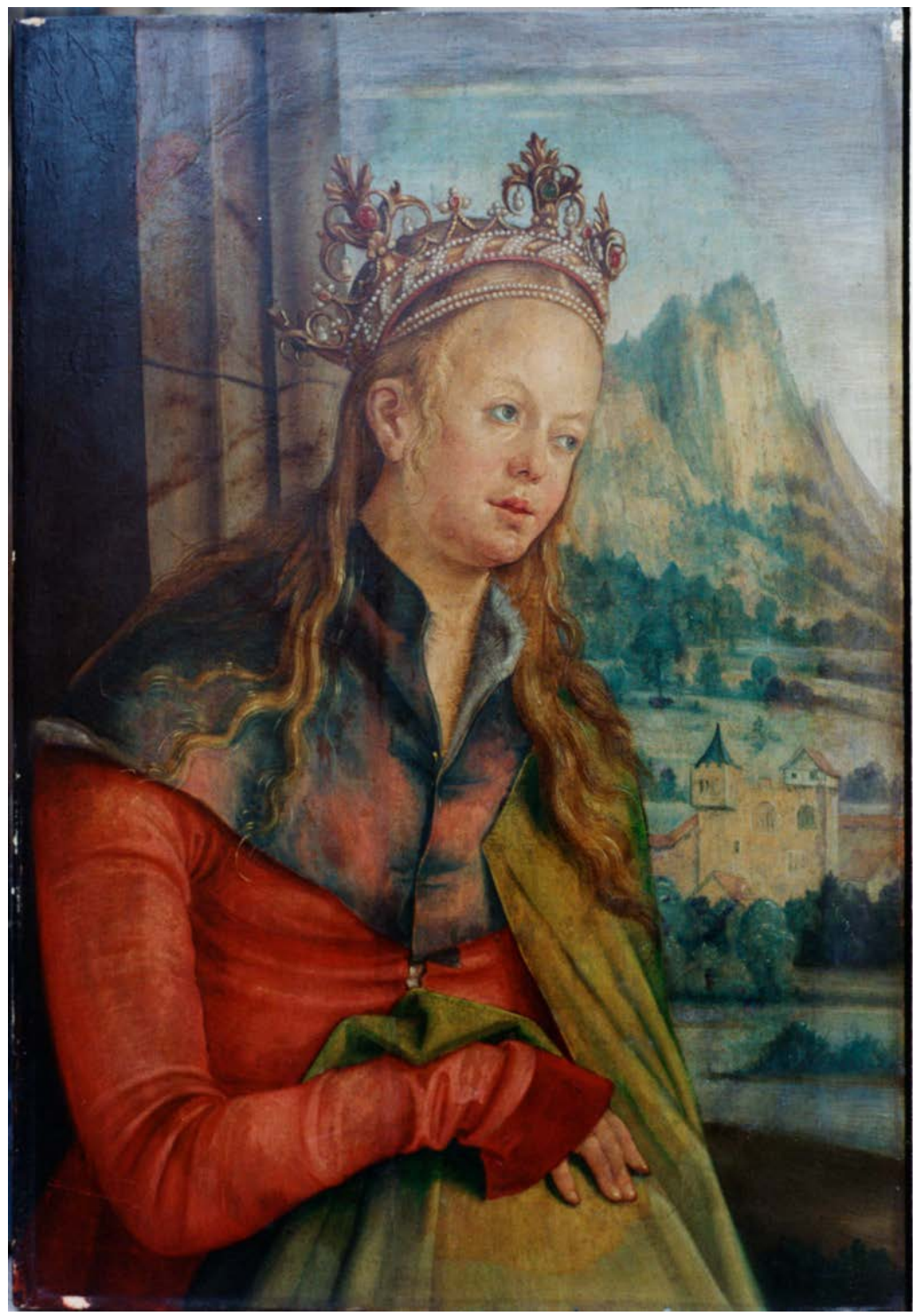

Il. 16. Hans Süss von Kulmbach, Św. Katarzyna, ok. 1511, Muzeum Narodowe w Krakowie - Muzeum Książąt Czartoryskich. Obraz w trakcie konserwacji-restauracji. Fot. M. Chmielewska 


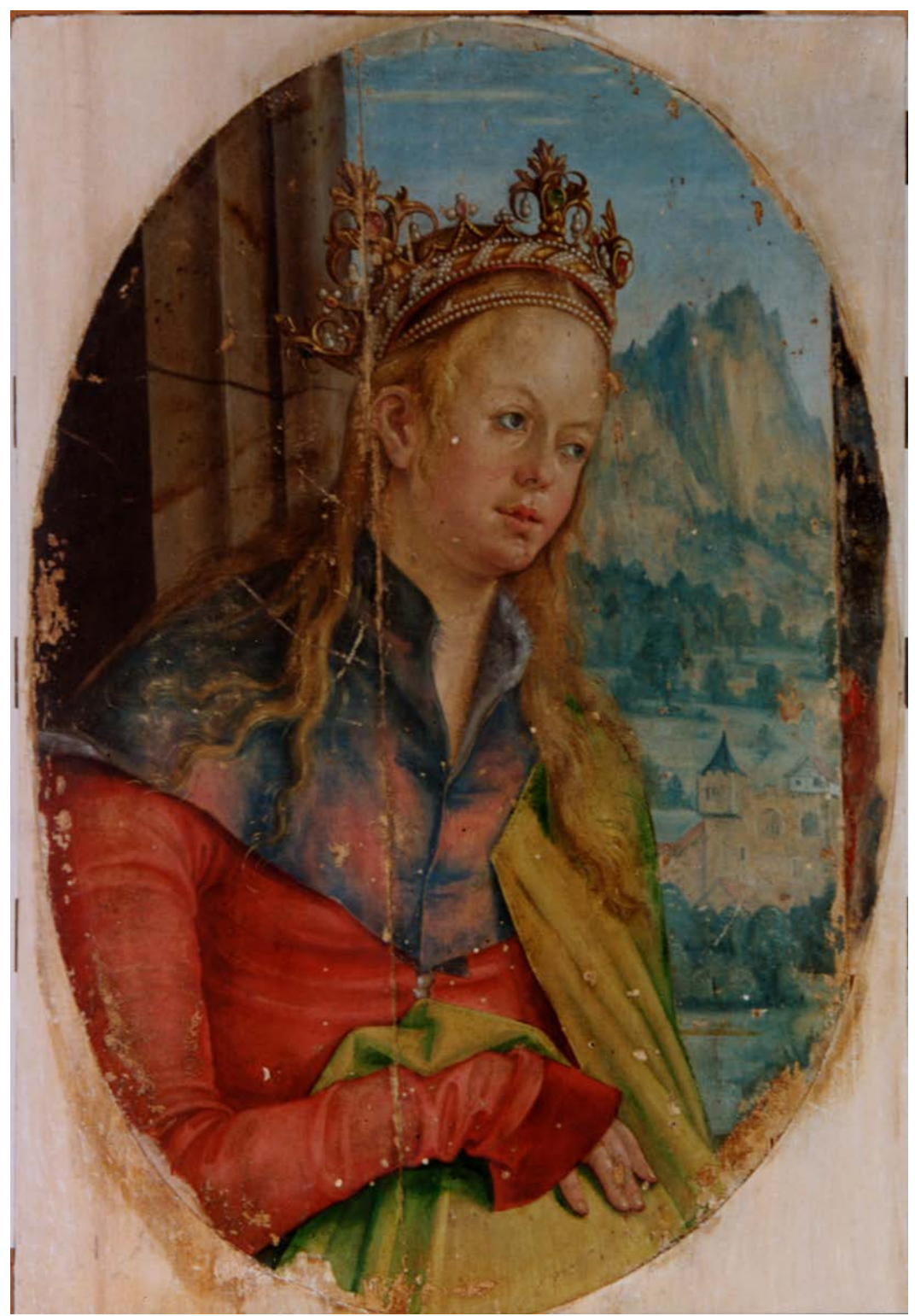

Il. 17. Hans Süss von Kulmbach, Św. Katarzyna, ok. 1511, Muzeum Narodowe w Krakowie - Muzeum Książąt Czartoryskich. Obraz w trakcie konserwacji-restauracji, stan po oczyszczeniu. Fot. M. Chmielewska 


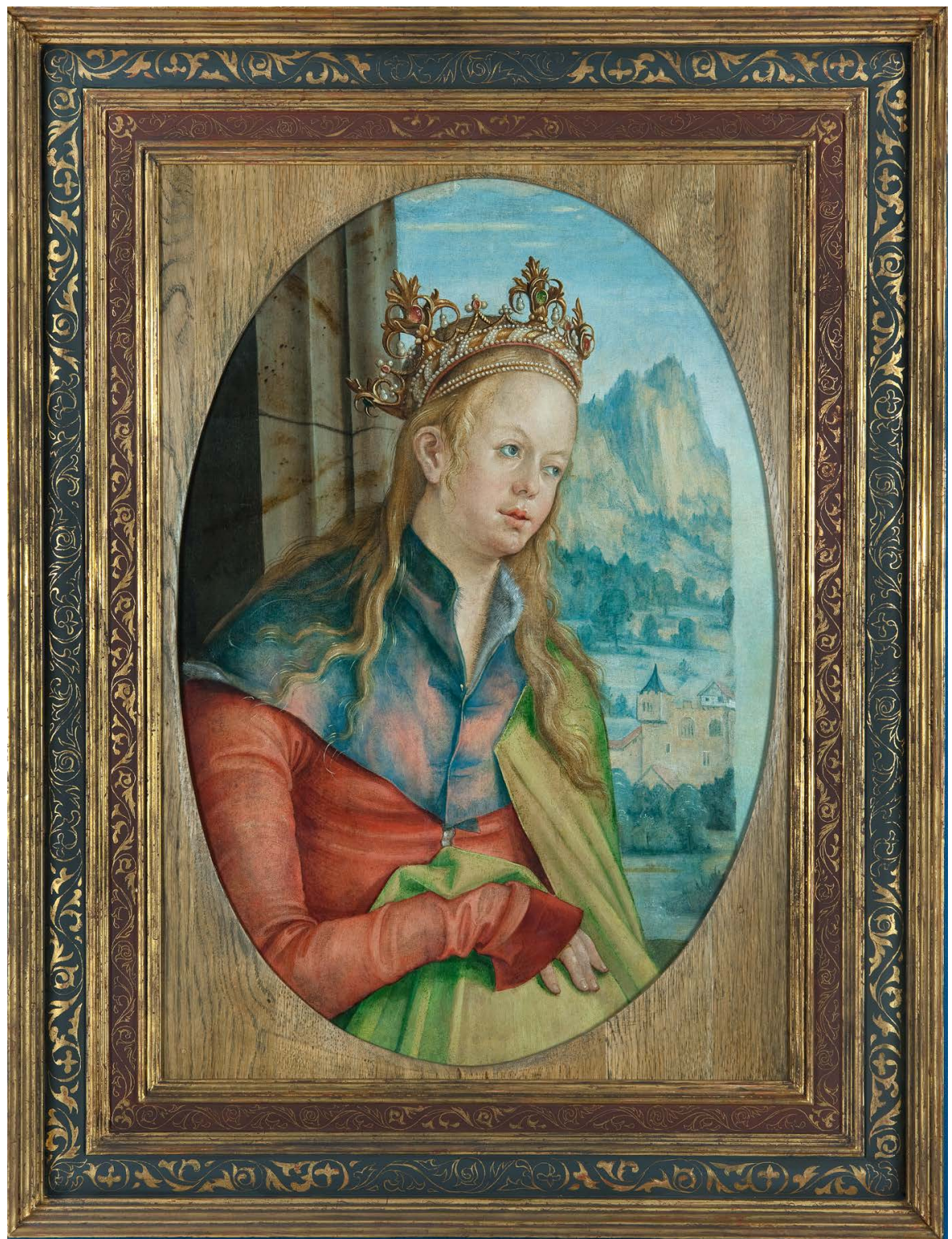

Il. 18. Hans Süss von Kulmbach, Św. Katarzyna, ok. 1511, Muzeum Narodowe w Krakowie - Muzeum Książąt Czartoryskich. Obraz po konserwacji-restauracji, w nowej ramie. Fot. Fundacja Książąt Czartoryskich 


\section{Bibliografia}

Chmielewska, Małgorzata. „Dokumentacja konserwatorska, Hans Süss von Kulmbach, nr inw. MNK XII-328.” Dokumentacja konserwatorska, Kraków 2000, Pracownia Konserwacji Malarstwa i Rzeźby Polichromowanej w Muzeum Książąt Czartoryskich w Krakowie.

Chmielewska, Małgorzata. „Kulmbach’s Saint Catherine of Alexandria from the Collection of the Czartoryski Museum in Krakow. Painting Conservation and Examination.” Poster na konferencji $5^{\text {th }}$ Meeting X-ray and Other Techniques in Investigation of the Objects of Cultural Heritage, Uniwersytet Jagielloński, Kraków, 2014.

Dec, Dorota. „Hans Suess von Kulmbach (†1522). 'Św. Katarzyna Aleksandryjska,' ok. 1511.” W Mistrz i Katarzyna. Hans von Kulmbach i jego dzieła dla Krakowa, red. Mirosław P. Kruk, Aleksandra Hola, i Marek Walczak, 311-312. Kraków: Muzeum Narodowe w Krakowie, 2019.

„Dokumentacja prac konserwatorskich i restauratorskich. Sześć obrazów na drewnie autorstwa Hansa Süssa z Kulmbachu ( 1480-1522) ze zbiorów Bazyliki Mariackiej w Krakowie.” Dokumentacja konserwatorsko-restauratorska. Praca zbiorowa. Opracowanie dokumentacji pisemnej Aleksandra Hola. Dokumentacja konserwatorska, Kraków 2015, wersja elektroniczna: Archiwum Bazyliki Mariackiej w Krakowie, sygn. ABMar, R323.

Grochowska-Angelus, Anna, i Katarzyna Novljaković. „Podpatrywanie mistrza - o Rembrandta ‘Krajobrazie z miłosiernym Samarytaninem' raz jeszcze.” W Wobec zabytku... Tradycje i perspektywy postaw. Studia dedykowane pamięci prof. Jerzego Remera, red. Elżbieta Pilecka i Juliusz Raczkowski, 221-242. Toruń: Wydawnictwo Naukowe UMK, 2010.

Hola, Aleksandra, i Masza Sitek. „Hans von Kulmbach (†1522), 'Św. Barbara’ (rewers, dolna część), 1511(?).” W Mistrz i Katarzyna. Hans von Kulmbach i jego dzieła dla Krakowa, red. Mirosław P. Kruk, Aleksandra Hola, i Marek Walczak, 307-310. Kraków: Muzeum Narodowe, 2019.

Hola, Aleksandra, Michał Płotek, Grażyna Korpal, Jacek Bagniuk, i Małgorzata Walczak. „Badania sześciu obrazów Hansa Süssa z Kulmbachu przedstawiających sceny z życia św. Katarzyny Aleksandryjskiej.” W Jako serce pośrodku ciała... Kultura artystyczna kościoła Mariackiego w Krakowie, red. Marek Walczak i Agata Wolska, 393-397. Kraków: Bazylika Mariacka w Krakowie / Wydawnictwo Towarzystwa Naukowego Societas Vistulana, 2020-2021.

Sitek, Masza. „Uczeń Dürera w Polsce’ - między źródłem a interpretacją.” W Mistrz i Katarzyna. Hans von Kulmbach i jego dzieła dla Krakowa, red. Mirosław P. Kruk, Aleksandra Hola, i Marek Walczak, 39-81. Kraków: Muzeum Narodowe, 2019.

Sokołowski, Marian. „Sprawozdanie z posiedzeń Komisyi Historyi Sztuki w dniu 20.II.1902.” Sprawozdania Komisji do Badań Historii Sztuki 8, z. 1-2 (1907): VI-VII. 
Stępowska, Konstancja. „Przyczynki do stosunków Kulmbacha z Polską i do jego działalności w Krakowie.” Sprawozdania Komisji do Badań Historii Sztuki 8, z. 1-2 (1907): XX-XXI.

Wolska, Agata, i Wojciech Walanus. „Wojenne i powojenne losy krakowskich dzieł Hansa Suessa z Kulmbachu.” W Mistrz i Katarzyna. Hans von Kulmbach i jego dzieła dla Krakowa, red. Mirosław P. Kruk, Aleksandra Hola, i Marek Walczak, 227-253. Kraków: Muzeum Narodowe, 2019.

Żmudziński, Jerzy. „Restauracja zabytków malarstwa sztalugowego w działalności Krakowskiego Towarzystwa Opieki nad Polskimi Zabytkami Sztuki i Kultury (1902-1926).” Rocznik Biblioteki PAN w Krakowie 42 (1997): 183-204.

Żmudziński, Jerzy. „Restauracja zabytków malarstwa ze zbiorów polskich w pracowni berlińskiego konserwatora Aloisa Hausera Mł. (1857-1919).” W Wobec zabytku... Tradycje i perspektywy postaw. Studia dedykowane pamięci prof. Jerzego Remera, red. Elżbieta Pilecka i Juliusz Raczkowski, 142-157. Toruń: Wydawnictwo Naukowe UMK, 2010. 